\title{
Experimental Study of a Diesel Engine Performance Fueled with Different Types of Nano-Fuel.
}

\author{
Abdulkhodor Kathum Nassir \\ Haroun A. K. Shahad \\ Department of Mechanical Engineering, University of Babylon, Babylon-Iraq \\ alhaji84@yahoo.com__ hakshahad@yahoo.com
}

\begin{abstract}
The aim of this experimental work is to study the effect of nanoparticles added to diesel fuel on engine performance characteristic. Nano fuels are prepared by adding $\mathrm{Al}_{2} \mathrm{O}_{3}$ or $\mathrm{TiO}_{2}$, both with particle size less than $45 \mathrm{~nm}$ of diesel fuel. Four doses of each type namely $(25,50,100$ and 150) ppm are prepared. These nanoparticles are blended with diesel fuel in varying volume fraction by the means of an electric mixer and an ultrasonicator. The Nano fuels are $\left(\mathrm{DF}+\mathrm{Al}_{2} \mathrm{O}_{3}\right)$ and $\left(\mathrm{DF}+\mathrm{TiO}_{2}\right)$. Physicochemical properties of nano fuels are measured and compared with these of neat diesel. The study shows that the addition of nanoparticles to diesel fuel improves its physical properties such as cetane number, thermal conductivity and viscosity. The influence of nanoparticles addition is very clear on the engine performance. The results show that the performance parameters are improved for example, brake thermal efficiency is increased from $19.4 \%$ for diesel to $21 \%$ and $25 \%$ for $\mathrm{DF}+\mathrm{Al}_{2} \mathrm{O}_{3}$ and $\mathrm{DF}+\mathrm{TiO}_{2}$ respectively, the brake specific fuel consumption (BSFC) is decreased by $8 \%$ and $20 \%$ for $\mathrm{DF}+\mathrm{Al}_{2} \mathrm{O}_{3}$ and $\mathrm{DF}+\mathrm{TiO}_{2}$ respectively, the brake specific energy consumption (BSFC) is decreased by $8 \%$ and $20 \%$ for $\mathrm{DF}+\mathrm{Al}_{2} \mathrm{O}_{3}$ and $\mathrm{DF}+\mathrm{TiO}_{2}$ respectively at $25 \mathrm{ppm}$ and $75 \%$ load. The exhaust gas temperature is $382^{\circ} \mathrm{C}$ for pure diesel while it is $417^{\circ} \mathrm{C}$ for $\mathrm{DF}+\mathrm{Al}_{2} \mathrm{O}_{3}$ and $353^{\circ} \mathrm{C}$ for $\mathrm{DF}+\mathrm{TiO}_{2}$. The peak pressure for pure diesel is 62 bar and it increases with $\mathrm{DF}+\mathrm{Al}_{2} \mathrm{O}_{3}$ to 66.2 bar as for $\mathrm{DF}+\mathrm{TiO}_{2}$ the peak pressure decreases to 57.2 bar at full load and $150 \mathrm{ppm}$.
\end{abstract}

Key words: - Nano fuel, Nanoparticle, Engine performance, Diesel engine.

\begin{tabular}{|c|c|c|c|c|c|}
\hline \multicolumn{2}{|c|}{ Nomenclature } & \multicolumn{2}{|l|}{ Unit } & \multirow{2}{*}{$\begin{array}{l}\text { Greek symbols } \\
\text { Dynamic viscosity }\end{array}$} & \multirow{2}{*}{$\begin{array}{l}\text { Unit } \\
\mathrm{kg} / \mathrm{m} \cdot \mathrm{sec}\end{array}$} \\
\hline $\mathrm{C}_{\mathrm{p}}$ & Specific heat & $\mathrm{J} / \mathrm{kg} \cdot{ }^{\circ} \mathrm{C}$ & $\mu$ & & \\
\hline $\mathbf{k}$ & Thermal conductivity & $\begin{array}{l}\mathrm{W} / \mathrm{m} \\
{ }^{\circ} \mathrm{C}\end{array}$ & $\rho$ & Density & $\mathrm{kg} / \mathrm{m}^{3}$ \\
\hline \multirow[t]{5}{*}{$\mathbf{m}$} & Mass & $\mathrm{kg}$ & $\varphi$ & $\begin{array}{l}\text { Solid volume fraction of } \\
\text { nanoparticles }\end{array}$ & $\%$ \\
\hline & & & \multicolumn{3}{|c|}{ Subscripts } \\
\hline & & & f & fuel & - \\
\hline & & & $\mathrm{nf}$ & Nanofuel & - \\
\hline & & & $\mathrm{p}$ & Nanoparticle & - \\
\hline
\end{tabular}


Journal of University of Babylon for Engineering Sciences, Vol. (26), No. (7): 2018.

\section{Introduction:}

The diesel engines are commonly used due to its reliable economy and operation. The increasing use of diesel combustion for powering automobiles has led to considerable increase in environmental pollution such as particulate emissions, carbon monoxide.....etc which causes the problem of global warming. The use of fuel with nano-particles catalyst is, currently, employed to reduce engine exhaust emissions and improve its performance.

[1] investigated the effect of $\mathrm{CeO}_{2}$ nanoparticles on the performance of compression ignition engine. The test engine was single cylinder, four stroke direct water cooled. The researchers found that $\mathrm{CeO}_{2}$ nanoparticles $(25 \mathrm{ppm})$ act as an oxygen donating catalyst and supply $\mathrm{O}_{2}$ for the oxidation of carbon monoxide (CO) and reduce NOx. They also reduce UHC and smoke emission and they reduced BSFC to $0.358(\mathrm{~kg} / \mathrm{kW} . \mathrm{hr})$. [2] investigated experimentally the effect of adding magnetic nanoparticle $(10 \mathrm{~nm})$ with doses of 0.4 and 0.8 Ferro by volume to the diesel fuel. The tested engine was a 4 stroke, 4 cylinder, $43 \mathrm{~kW}$, water cooled and constant speed (4800 $\mathrm{rpm})$. The results showed that these addition enhanced the performance by increasing the BTE by $12 \%$ and decreasing BSFC by $11 \%$. [3] presented an experimental investigation of the effect of adding $\mathrm{Al}_{2} \mathrm{O}_{3}$ on fuel combustion process. The size of nanoparticles was $(10 \mathrm{~nm})$. This addition leads to enhancements of the combustion features and a reduction in the formation of carbon monoxide and improvement of combustion stability and efficiency. [4] the test was conducted on a single cylinder, 4 stroke and stationary diesel engine. Different doses of $\mathrm{CeO}_{2}$ nanoparticles (from 5 to $35 \mathrm{ppm}$ ) were used. Thermal efficiency was improved by about $6 \%$ as compared with that of neat diesel fuel for $35 \mathrm{ppm}$ dose higher loads. Fire point, flash point and viscosity of fuel were increased with the increasing of the dose of nano particles. [5] examined the addition of $\mathrm{ZnO}$ nanoparticles effect on the performance of single cylinder, four stroke vertical and cool water diesel engine. The size of the nanoparticles was (1-100) nm with two doses of $250 \mathrm{ppm}$ and $500 \mathrm{ppm}$. $\mathrm{ZnO}$ additive shortened the ignition delay, The peak pressure increased from 69 bar for diesel fuel to 76.6 and 78 bar for $(\mathrm{DF}+250 \mathrm{ppm} \mathrm{ZnO})$ and $(\mathrm{DF}+500 \mathrm{PPM} \mathrm{ZnO})$ respectively. The brake thermal efficiency was increased from $35.82 \%$ for diesel fuel to $36.8 \%$ and $37.35 \%$ for $(\mathrm{DF}+250 \mathrm{PPMZnO})$ and $(\mathrm{DF}+500 \mathrm{ppm} \mathrm{ZnO})$ respectively. [6] studied experimentally the effect of addition of cerium oxide to the neat diesel fuel on the performance and emission in a four stroke, cool water, constant speed $1700 \mathrm{rpm}$ and four cylinder compression ignition engine whose rate power is $15 \mathrm{HP}$. The dosages of nanoparticles were 10, 20, 30 and 40ppm. The specific fuel consumption decreased to $0.5(\mathrm{~kg} / \mathrm{kW} . \mathrm{hr})$ for $\left(\mathrm{DF}+30 \mathrm{ppmCeO}_{2}\right)$. [7] studied the effect of Nano additive on the performance of a $\mathrm{CI}$ engine. The tests were performed on a 4 stroke, single cylinder, $5.2 \mathrm{~kW}$ and water cooled with constant speed $1500 \mathrm{rpm}$, diesel engine. The Nano additive were Aluminum (5-150nm), iron (30-60nm) and boron $(80-100 \mathrm{~nm})$. It was found that the ignition delay reduced together with BSFC. Brake thermal efficiency increased by $33 \%$. [8] investigated experimentally the effect of $\mathrm{Al}_{2} \mathrm{O}_{3}$ as an additive to the biodiesel. The test was done on a single cylinder, direct injection (DI) and water cooled engine. They used $25 \%$ of zizipus jujube methyl ester blended fuel (ZJME25). Along with ZJME25 aluminum oxide nanoparticles were added as additive in mass fraction of 25 ppm (AONP25) and $50 \mathrm{ppm}$ (AONP50) was used. Brake specific fuel consumption (BSFC) decreased by 6\% when 50ppm (AONP50). Brake thermal efficiency was increased by $2.5 \%$ with dosing level of 50ppm (AONP50). Cylinder pressure was increased as 66.115 bar and 69.946 bar for 25ppm (AONP25), 50ppm (AONP50) 
respectively. [9] investigated experimentally the effect of alumina oxide $\mathrm{Al}_{2} \mathrm{O}_{3}$ nano additive on performance and emission of a direct injection diesel engine fueled with methyl ester of neem oil. The alumina oxide nanoparticles were mixed in various proportions from $100 \mathrm{ppm}, 200 \mathrm{ppm} \& 300 \mathrm{ppm}$ with biodiesel. The size of nanoparticles was $(1-110 \mathrm{~nm})$. It was found that brake thermal efficiency (BTE) was increased by $2.17 \%, 4.23 \%$ and $3.49 \%$ for $\left(\mathrm{MENO}+100 \mathrm{ppm} \mathrm{Al}_{2} \mathrm{O}_{3}\right),(\mathrm{MENO}+200$ ppm $\left.\mathrm{Al}_{2} \mathrm{O}_{3}\right)$ and $\left(\mathrm{MENO}+300 \mathrm{ppm} \mathrm{Al}_{2} \mathrm{O}_{3}\right)$ respectively. The addition of nanoparticles reduced the ignition delay priod and reduced heat release rate for all biodiesel blends.

[10] studied theoretically and experimentally the effect of nanoparticles additive on the performance of compression ignition engine. The nanoparticles used were alumina $\left(\mathrm{Al}_{2} \mathrm{O}_{3}\right)$ with particle size around $50 \mathrm{~nm}$, while density was $3.97 \mathrm{~g} / \mathrm{ml}$ and dosages of $25 \mathrm{ppm}, 50 \mathrm{ppm}$ and $75 \mathrm{ppm}$. The test was done on a single cylinder, 4 stroke cycles, horse power was $7.5 \mathrm{hp}$, constant speed was $1800 \mathrm{rpm}$, compression ratio was 17.5 and water cooled. It was found that fuel flash point increased from $55^{\circ} \mathrm{C}$ (diesel) to $62^{\circ} \mathrm{C}\left(\mathrm{DF}+75 \mathrm{ppm} \mathrm{Al}_{2} \mathrm{O}_{3}\right)$, peak pressure increased from 54 bar (diesel) to 58 bar for (DF+75ppm), brake thermal efficiency increased to $39.6 \%$ at full load and dosing level of $75 \mathrm{ppm}$. The lowest brake specific fuel consumption was $0.224(\mathrm{~kg} / \mathrm{kW}$.hr) for $\mathrm{DF}+\mathrm{Al}_{2} \mathrm{O}_{3}$. [11] studied the emission and consumption in the diesel in C.I engine, direct injection (DI), and water cooled four cylinders, in line and natural aspirated with constant speed $(1500 \mathrm{rpm})$. Nano particles which had been used was cerium and aluminum with different doses. There was a significant improving in the thermal brake efficiency by about $6 \%$. The brake specific fuel consumption reduces to $6 \%$. [12] studied experimentally the influence of addition of titanium oxide $\left(\mathrm{TiO}_{2}\right)$ nanoparticle to diesel fuel in a compression ignition engine. The experiments were conducted at constant speed of $1500 \mathrm{rpm}$ and for compression ratio 17.5. The size of nanoparticles was $10-20 \mathrm{~nm}$ and the dosing level was $80 \mathrm{mg} / \mathrm{L}$. They noticed an increase in the brake thermal efficiency by $0.9 \%$ at full load when titanium oxide nanoparticles were added. They also found that the addition of titanium oxide diesel fuel reduced the brake specific fuel consumption by $22 \%$. [13] examined the effect of addition of Nano fuel on the performance and emission of diesel engine using stationary, single cylinder, four stroke, constant speed $1500 \mathrm{rpm}$ and water cooled (CI) engine. Aluminum oxide $\left(\mathrm{Al}_{2} \mathrm{O}_{3}\right)$ was used as nanoparticles with size between $(5-150 \mathrm{~nm})$. They found that BSFC decreased by $7 \%$ compared to that of pure diesel. Peak pressure increased at full load for the Nanofuel to about 62. Exhaust gas temperature was increased by $8 \%$ and brake thermal efficiency (BTE) by $9 \%$ as compared to their counterpartsin pure diesel. The effect of $\left(\mathrm{CeO}_{2}\right)$ Cerium Oxide as an additive in diesel fuel, on fuel properties and on engine performance and emission were studied experimentally by [14] investigated experimentally the effect of zinc oxide $(\mathrm{ZnO})$ on performance and emission characteristics of diesel engine. The used dose was $50 \mathrm{ppm}$ and $100 \mathrm{ppm}$. The tests were done on cool water, constant speed of $(1500 \mathrm{rpm})$ with the fuel injection of pressure (400 bar), varying load, four cylinders, in line and natural aspirated direct injection fait diesel engine. Thermal efficiency was increased and the brake specific fuel consumption decreased with the increase of nanoparticles dose. [15] investigated the effect of $\left(\mathrm{Al}_{2} \mathrm{O}_{3}\right)$ aluminum oxide on performance, emission and the characteristic of combustion of a single vertical cylinder diesel engine, 4 stroke, $4.4 \mathrm{~kW}$ and constant speed $1500 \mathrm{rpm}$ with $25 \mathrm{ppm}$ and 50ppm blended with diesel fuel. The size of nanoparticles was about $60-70 \mathrm{~nm}$. It was found that using $25 \mathrm{ppm}$ and $50 \mathrm{ppm}$ reduced SFC by $7 \%, 4 \%$ respectively. Moreover, the brake thermal efficiency increased by $6 \%$ and $3 \%$ for $25 \mathrm{ppm}$ and 50ppm respectively. Peak cylinder pressure and temperature 
were increased by shorting the diffusion combustion of nanoparticle blended fuels. [16] performed an experimental comparative study between the addition of $\mathrm{Al}_{2} \mathrm{O}_{3}$ and $\mathrm{CuO}$ to the neat diesel on the performance and emission of compression ignition engine. Mechanical homogenizer and an ultrasonic devices were used for the purpose of mixing neat diesel fuel with nanoparticle under various mass fraction. They found that $\mathrm{Al}_{2} \mathrm{O}_{3}$ and $\mathrm{CuO}$ reduced the brake specific fuel consumption by $0.5 \%$ and $1.2 \%$ respectively.

\section{Experimental Setup}

The experiments were conducted to study the effect of nanoparticles addition on the performance of a single cylinder 4-stroke, water-cooled direct injection diesel engine with a displacement volume of $\left(553 \mathrm{~cm}^{3}\right)$, variable compression ratio, developing $3.7 \mathrm{~kW}$ at $1500 \mathrm{rpm}$. The engine was fitted with a conventional fuel injection system. The engine has a three holes nozzle of $0.2 \mathrm{~mm}$ diameter separated at 120 degrees, inclined at an angle of 60 degrees to the cylinder axis. The injector opening pressure recommended by the manufacturer is 120 bar. The complete rig set up is shown in plate (1) and schematically in fig (1). The data acquisition and engine control system is shown in plate (2). The system records the pressure via crank angle diagram (p, $\Theta)$, engine speed $(\mathrm{rpm})$ and temperature of exhaust gases.

\section{Fuel and Nano Fuel Preparation}

The fuel used in this study is gas oil (diesel) $\mathrm{C}_{12.3} \mathrm{H}_{22.2}$, with a density of 844.3 $\mathrm{kg} / \mathrm{m}^{3}$ and a dynamic viscosity of $2.778^{*} 10^{-3}(\mathrm{~kg} / \mathrm{m} . \mathrm{s})$. Two types of nanoparticles are chosen, namely $\mathrm{Al}_{2} \mathrm{O}_{3}$ and $\mathrm{TiO}_{2}$ with particle size less than $45 \mathrm{~nm}$ to be blended with the diesel fuel. The nanoparticles dose was chosen to be 25, 50, 100 and $150 \mathrm{ppm}$. The mass of nanoparticles required for each dose is calculated using equation (1) below [17] [18].

$$
\phi=\frac{\frac{m_{p}}{\rho_{p}}}{\frac{m_{p}}{\rho_{p}}+\frac{m_{f}}{\rho_{f}}}
$$

The physical properties of the nanoparticles and pure diesel fuel used to prepare Nano fuel are shown in table (1).

Table (1) shows the physical properties of nanoparticles and diesel fuel [19].

\begin{tabular}{|c|c|c|c|c|}
\hline Substance & $\begin{array}{c}\text { Density } \\
\left(\mathbf{k g} / \mathbf{m}^{\mathbf{3}}\right)\end{array}$ & $\begin{array}{c}\text { Dynamic } \\
\text { viscosity*10 } \\
(\mathbf{k g} / \mathbf{m} . \mathbf{3})\end{array}$ & $\begin{array}{c}\text { Specific } \\
\text { heat(J/kg.K) }\end{array}$ & $\begin{array}{c}\text { Thermal } \\
\text { conductivity(W/m. }\end{array}$ \\
\hline $\mathbf{A l}_{\mathbf{2}} \mathbf{O}_{\mathbf{3}}$ & 3970 & ------ & 765 & 40 \\
\hline $\mathbf{T i O}_{\mathbf{2}}$ & 4230 & ------ & 710 & 09 \\
\hline Diesel fuel & 844.3 & 2.778 & ---- & ------ \\
\hline
\end{tabular}


Journal of University of Babylon for Engineering Sciences, Vol. (26), No. (7): 2018.

Table (2) shows the mass of nanoparticles required for each dose for both types as calculated by equation (1).

Table (2) mass of nano-particles (for five liters of fuel).

\begin{tabular}{|c|c|c|c|}
\hline $\begin{array}{c}\text { Volume ratio } \\
(\mathbf{p p m})\end{array}$ & $\phi \%$ & $\begin{array}{c}\text { Mass of particles } \\
\left(\mathbf{m}_{\mathbf{p}}\right)(\mathbf{g})\left(\mathbf{A l}_{\mathbf{2}} \mathbf{O}_{\mathbf{3}}\right)\end{array}$ & $\begin{array}{c}\text { Mass of particles } \\
\left(\mathbf{m}_{\mathbf{p}}\right)(\mathbf{g})(\mathbf{T i O} \mathbf{})\end{array}$ \\
\hline $\mathbf{2 5}$ & 0.0025 & 0.4963 & 0.529 \\
\hline $\mathbf{5 0}$ & 0.005 & 0.993 & 1.058 \\
\hline $\mathbf{1 0 0}$ & 0.01 & 1.986 & 2.116 \\
\hline $\mathbf{1 5 0}$ & 0.015 & 2.979 & 3.174 \\
\hline
\end{tabular}

The measured quantity of nanoparticles is added to five litter $(5 \mathrm{~L})$ of diesel fuel and mixed continuously for one hour by a mixer, see plate (3), to ensure the spreading of nanoparticles within the diesel fuel to prevent aggregation of particles quickly. An ultrasonic cleaner type (JTS-1018), see plate (4), is used to complete the mixing process. The mixing process continues for another six hours.

\section{Results and Discussion.}

\subsection{Fuel Consumption:}

Figures (1and 2) show the effect of nanoparticles blending on fuel consumption at full load for different speeds. It is shown that fuel consumption of pure diesel increases with speed due to increase of fraction. The figures below show that the $25 \mathrm{ppm}$ nanoparticles dose give minimum fuel consumption for all speeds and with both types of nanoparticles. However, the effect of $\mathrm{TiO}_{2}$ is more significant. The increase of nanoparticle dose beyond 25ppm increases fuel consumption but it is still less than that for the pure diesel. It is thought that the nanoparticles act as oxygen buffer to improve combustion process and release as maximum as possible of heat [17].

\subsection{Equivalence ratio:}

Figures(3and 4) show that the equivalence ratio $(\varphi)$ reached its minimum value with $25 \mathrm{ppm}$ for both types of nanoparticle and increased with the further increase in dose level. The reeducation in $\varphi$ with $\mathrm{Al}_{2} \mathrm{O}_{3}$ and $\mathrm{TiO}_{2}$ is $7 \%$ and $22.5 \%$ respectively. This reduction is due to the lower fuel consumption which means efficient combustion process caused by the improved fuel properties.

\subsection{Volumetric Efficiency: $\eta_{V}$}

Figures (5and 6) show that the addition of $\mathrm{Al}_{2} \mathrm{O}_{3}$ and $\mathrm{TiO}_{2}$ to diesel fuel produces a contradicting effect on volumetric efficiency where $\mathrm{Al}_{2} \mathrm{O}_{3}$ reduces it slightly, while $\mathrm{TiO}_{2}$ increases it slightly. This can be related to higher cylinder pressure and temperature caused by the addition of $\mathrm{Al}_{2} \mathrm{O}_{3}$ as it will be clarified later in this paper.

\subsection{Brake Thermal Efficiency:}

The effect of nanoparticles addition to diesel fuel on brake thermal efficiency is shown in figures (7and 8) for different loads. It is noticed that the addition of both types of nanoparticles improves the brake thermal efficiency but the maximum improvement is noticed at 25ppm dose. However the effect of $\mathrm{TiO}_{2}$ is higher than that of $\mathrm{Al}_{2} \mathrm{O}_{3}$. The maximum brake thermal efficiency obtained is $21 \%$ for $\mathrm{Al}_{2} \mathrm{O}_{3}$ and $24.9 \%$ for $\mathrm{TiO}_{2}$. This improvement in brake thermal efficiency is contributed to the better combustion 
process caused by the presence of nanoparticles. The BTE is increased by $8.2 \%$ and $28.44 \%$ for $\mathrm{Al}_{2} \mathrm{O}_{3}$ and $\mathrm{TiO}_{2}$ respectively at $75 \%$ load and $25 \mathrm{ppm}$.

\subsection{Brake specific fuel consumption (BSFC):}

Figures (9and10) show the variation of brake specific fuel consumption (BSFC) with dose levels of both types of nanoparticles. The result shows that the brake specific fuel consumption reduces with the addition of nanoparticles. However, the maximum reduction obtained is with $25 \mathrm{ppm}$ dose which is $8 \%$ and $20 \%$ for $\mathrm{Al}_{2} \mathrm{O}_{3}$ and $\mathrm{TiO}_{2}$ respectively. It is thought that the nanoparticles act as an oxygen buffer which improves the combustion process and enhances the heat release.

\subsection{Brake specific Energy consumption (BSEC):}

Figures (11and 12) show the variation of brake specific energy consumption (BSEC) with dose level of nanoparticles. The BSEC reduces with both types of nanoparticles, but the reduction is more with $\mathrm{TiO}_{2}$. $\mathrm{DF}+25 \mathrm{ppm} \mathrm{Al}_{2} \mathrm{O}_{3}$ shows a decrease of about $7 \%$, but $\mathrm{DF}+25 \mathrm{ppmTiO}_{2}$ shows around $20 \%$ reduction. This is due to improvement of fuel properties caused by the presence of nanoparticles which improves combustion process. It is also thought that nanoparticles act as an oxygen buffer which improves combustion process and leads to a less fuel consumption.

\subsection{Exhaust Gas Temperature:}

Figures (13and 14) show the effect of nanoparticles addition on exhausted gas temperature at different loads and different doses. It is shown that $\mathrm{TiO}_{2}$ nanoparticles reduce $\mathrm{T}_{\mathrm{exh}}$ and this effects increases as the dose increases. This is due to the relatively shorter delay period and lesser maximum cylinder pressure as it will be explained later. However, the addition of $\mathrm{Al}_{2} \mathrm{O}_{3}$ increases $\mathrm{T}_{\text {exh }}$ for all loads. This increase may be due to the higher maximum cylinder pressure caused by the pressure of $\mathrm{Al}_{2} \mathrm{O}_{3}$ nanoparticles.

\subsection{Cylinder Pressure:}

Figures $(15,16$ and 17) show the cylinder pressure history diagram for pure diesel, $\mathrm{DF}+25 \mathrm{ppm} \mathrm{Al}_{2} \mathrm{O}_{3}$ and $\mathrm{DF}+25 \mathrm{ppm} \mathrm{TiO}_{2}$. The comparison shows that $\mathrm{Al}_{2} \mathrm{O}_{3}$ nanoparticles increases the maximum cylinder while the $\mathrm{TiO}_{2}$ reduces the maximum cylinder pressure as compared to that of the pure diesel. The effect of $\mathrm{TiO}_{2}$ may be due to the shorter delay period and hence the less premixed fraction of combustion process. For example at $25 \%$ load the maximum pressure is reduced from 57 bar for pure diesel to 56.5 bar for $\mathrm{DF}+25 \mathrm{ppm} \mathrm{TiO}_{2}$. The adverse effect occurs with the addition of $\mathrm{Al}_{2} \mathrm{O}_{3}$ nanoparticles where the maximum cylinder pressure is increased to 57.5 bar since $\mathrm{Al}_{2} \mathrm{O}_{3}$ has a little effect on delay period though it improves combustions process. As the maximum cylinder pressure timing moves closer to TDC the effective expansion process becomes longer and more power is produced and hence better brake thermal efficiency is gotten. Figures $(18,19,20,21,22$ and 23) show the cylinder pressure history for 50ppm, 100ppm and $150 \mathrm{ppm}$ of $\mathrm{Al}_{2} \mathrm{O}_{3}$ and $\mathrm{TiO}_{2}$ at $25 \%$ load. The same trends are noticed in figures (16and 17). As the maximum cylinder pressure timing moves closer to TDC the effective expansion process becomes longer and more power is produced and hence better brake thermal efficiency is obtained. Figures (24and25) show the variation of maximum pressure with nanoparticles dose. The maximum pressure is increased with the addition of $\mathrm{Al}_{2} \mathrm{O}_{3}$. This increase is due to the high pressure in the small volume then the cylinder pressure increases, so the increasing in 
peak pressure means an advance toward the TDC. The reduction in peak pressure means delay of TDC. Figures (26and 27) show the timing of maximum pressure with the dose level of nanoparticles. It is clear that the $\mathrm{P}_{\max }$ with $\mathrm{Al}_{2} \mathrm{O}_{3}$ approaches the TDC more than it does with the $\mathrm{TiO}_{2}$. Also figs (26 and 27) show the advancing with $\mathrm{Al}_{2} \mathrm{O}_{3}$ and delaying with $\mathrm{TiO}_{2}$. Figs (28 and 29) show the variation of the differences in maximum pressure with nanoparticles dose. The maximum pressure with $\mathrm{Al}_{2} \mathrm{O}_{3}$ approaches ATDC, while $\mathrm{P}_{\max }$ with $\mathrm{TiO}_{2}$ is a bit faraway from ATDC.

\section{Conclusions}

1. The equivalence ratio $(\varphi)$ decreases by $25 \mathrm{ppm}$ for both types of nanoparticles, but the effect of $\mathrm{TiO}_{2}$ is more than that of $\mathrm{Al}_{2} \mathrm{O}_{3}$.

2. The brake thermal efficiency with $\mathrm{TiO}_{2}(25 \mathrm{ppm})$ is better than that with $\mathrm{Al}_{2} \mathrm{O}_{3}$ (25ppm). The maximum BTE for $\mathrm{Al}_{2} \mathrm{O}_{3}$ is $(21 \%)$ and for $\mathrm{TiO}_{2}$ it is $(24.94 \%)$, at $25 \mathrm{ppm}$.

3. The maximum reduction in $\mathrm{BSFC}$ is obtained at a dose of $25 \mathrm{ppm}$ which is $8 \%$ and $20 \%$ for $\mathrm{Al}_{2} \mathrm{O}_{3}$ and $\mathrm{TiO}_{2}$ respectively, while the reduction in $\mathrm{BSEC}$ is $7 \%$ and $20 \%$ for $\mathrm{Al}_{2} \mathrm{O}_{3}(25 \mathrm{ppm})$ and $\mathrm{TiO}_{2}(25 \mathrm{ppm})$ respectively.

4. The exhausted gas temperature decreases with the increase of $\mathrm{TiO}_{2}$ the dosage, but it increases with the increase of $\mathrm{Al}_{2} \mathrm{O}_{3}$ the dosage.

5. The peak pressure decreases with $\mathrm{TiO}_{2}$ as compared to that of the pure diesel i.e (from 62.034 bar to 57.18 bar), while it increases with $\mathrm{Al}_{2} \mathrm{O}_{3}$ nanoparticles.

6. The timing of maximum pressure moves closer to TDC with $\mathrm{Al}_{2} \mathrm{O}_{3}$ nanoparticles addition than it does with $\mathrm{TiO}_{2}$.

\section{References}

[1] Arul M.S. V,Anand R.B.,Udayakumar M.,"Effects of cerium oxide nanoparticle addition in diesel and diesel-biodiesel-ethanol blends on the performance and emission characteristics of a CI engine". ARPN Journal of Engineering Applied Sciences, 4:1-6, 2009.

[2] Shafii, MR., Daneshvar, P., Jahani, NA. and Mobini, K., "Effect of ferrofluid on the performance and emission patterns of a four-stroke diesel engine". Advances in Mechanical Engineering, Vol (3), pp.529-649, 2011.

[3] Solara G., "Experimental analysis of the influence of inert nano-additives upon combustion of diesel sprays". Nanoscience and Nanotechnology, 2(4), pp. 129$133,2012$.

[4] Ajin C. sajeevan and V. Sajith, "Engine emission Reduction using catalytic nanoparticles an experimental investigation". Hindaw publishing corporation, Journal of Eng Vol (1) 9 pages, 2013.

[5] Selvaganapthy A., Sundar A., Kumaragurubaran B. and Gopal P., "An Experimental Investigation to Study the Effects of Various Nano Particles with Diesel on Di Diesel Engine". ARPN Journal of Science and Technology, 3(1).pp:112-115, 2013. 
Journal of University of Babylon for Engineering Sciences, Vol. (26), No. (7): 2018.

[6] Nithan and Muhammad, "performance and emission characteristics of a C.I engine with cerium oxide nanoparticles as additive to diesel". International Journal of Science and Research, 2013.

[7] Mehta R.N., Chakraborty M. and Parikh P.A., "Nanofuels Combustion, engine performance and emissions". Fuel: 120, pp.91-97, 2014.

[8] Syed A.C., Saravanan G.G. and Kanna M., "Expermental investigation on a CROI system assited diesel engine fueled with aluminium oxide nanoparticles blended biodiesles". Alexandrsa engineering Journed 54, pp. 361- 358, 2015.

[9] Balaji G. a maini B. and Cheralathan M.," Influence of Alumina oxide nanoparticles on the performance and emission in a methyl ester of neem oil fueled Al diesel engine". Renewable Energy 74, pp: 910-916, 2015.

[10] Babu K.B.,"Theoretical and Experimant validation of performance and emission characteristics of nano additive blended diesel engine". Int.Jou. of Researching Aeronautical and Mech.Eng.Vol.3 Issue.5.pp: (3-8), 2015.

[11] Saraee S. H., Jafarmadar S., Taghavifor H., Asharfi S.J., "Reduction of emissions and fuel consumption in compression ignition engine using nanoparticles" International Journal of Environmental Science and Technology. july 2015 , V12 pp: 2245-2262, july 2015 .

[12] Rolvin D'Silva, Binu K.O, Thirumaleshwara Bhat., "Performance and Emission characteristics of a C.1. Engine fuelled with diesel and $\mathrm{TiO}_{2}$ nanoparticles as fuel additive" Materials Today Vol 2, pp: 3728-3735, 2015.

[13] Mohan N., Sharma M., singh R.C. and Pandey R.K.,"Performance study of Diesel engine using Nanofuel”. International. Conference of Advance Research and innovation pp: 457-460, 2015.

[14] Hamadi A. S., Dhahad H. A., Noaman R., Kidher T., Suhail S., and Abass Q., "An experimental investigates to study the effect of Zinc oxide nanoparticles fuel additives on the performance and emissions charactristics of diesel engine" Chemical and Petrochemical Research Centre, Ministry of Industry and Minerals, Baghdad, Iraq, 2016.

[15] Raj M. N., Gajendiran M., Pitchardi k., and Nallusam N., "Investigation on aluminium oxide nano particles blended fuel combustion, performance and emission characteristics of a diesel engine". Journal of chemical and pharmaceutical Research, 8(3): 246- 257, 2016.

[16] Gumus S., OL.C8n H., Ozbey M and Topaloglu B., "Aluminum oxide and copper oxide nanodiesel fuel properties and usage in a compression ignition engine". Fuel, 163, pp.80-87, 2016.

[17] Nasir A.K., "Experimental Study of Effect of Nano-Particles Addition to Diesel Fuel on Heat Release and Emission Characteristics of Diesel Engine" M.Sc.dissertation (Mechanical Engineering) in Babylon University, 2018.

[18] K Hameed H., R.Qusy, "Experimental Investigation to Heat Transfer Augmentation in a Car Radiator Worked with Water-Magnesium-Oxide) Nano fluid" Journal of University of Babylon, vol 25, no.4, pp.1179-1193, 2017. 
[19] Al-Ali N. A. A.,"'Heat transfer enhancement in a uniformly heated tube using Nano fluids", M.Sc. dissertation (Mechanical Engineering) in Babylon University, 2014.

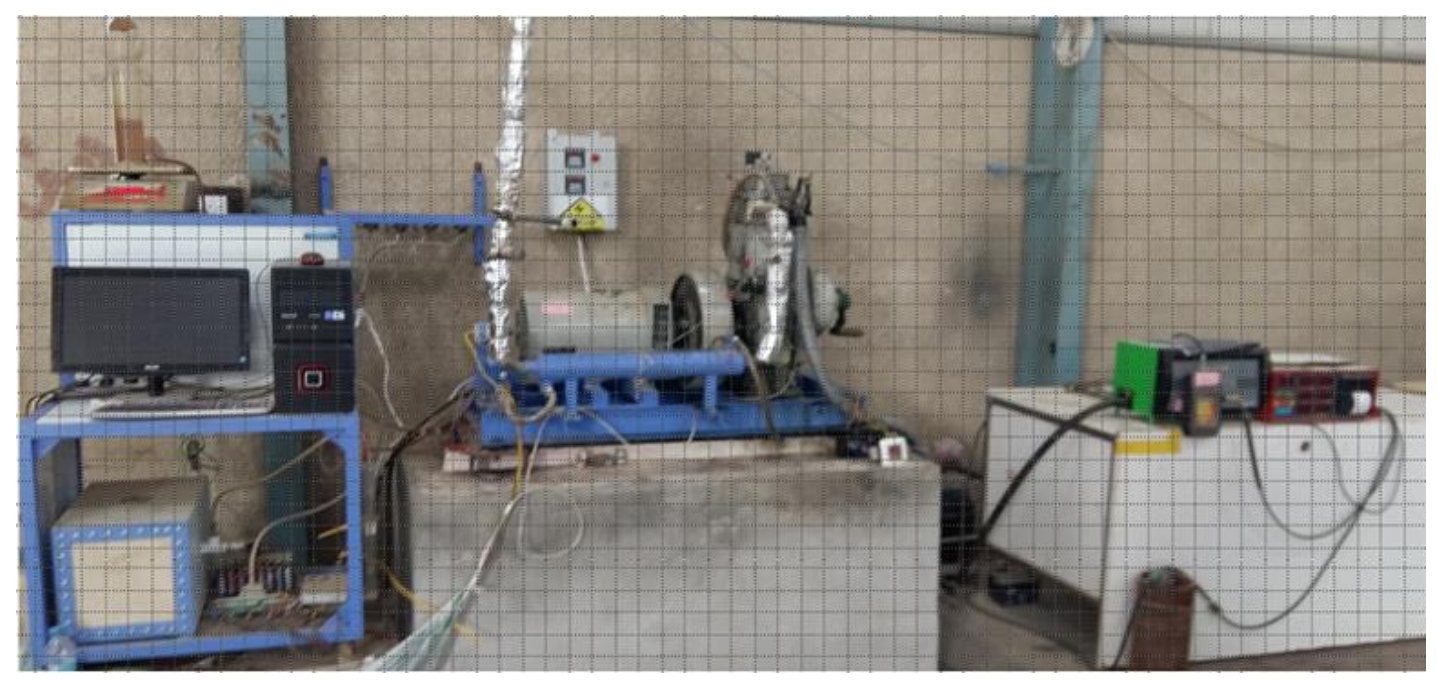

Plate (1) Front View of the Experimental Set Up

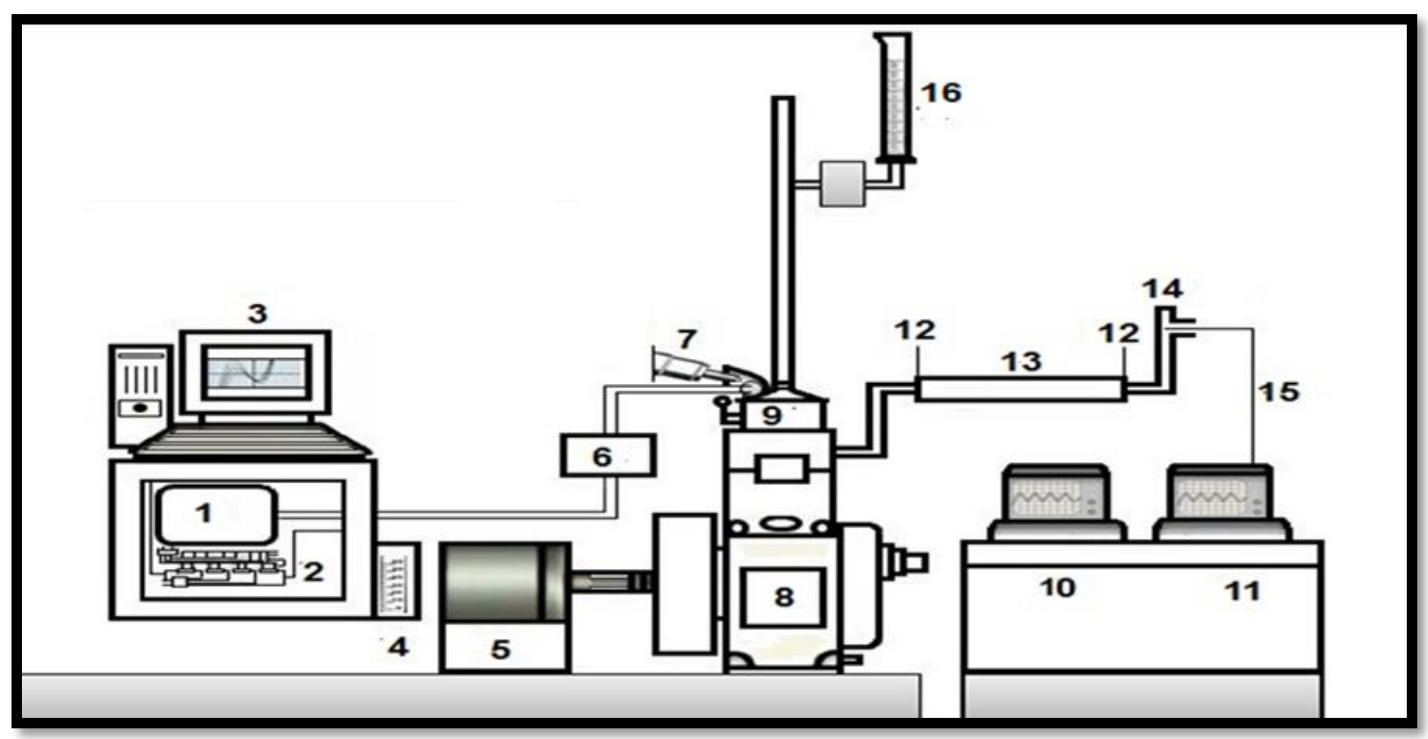

\begin{tabular}{|r|c|c|c|c|c|}
\hline 1 & Air surge tank & 7 & Fuel injector & 13 & Calorimeter \\
\hline 2 & Data Logger & 8 & Engine block & 14 & Silencer tip \\
\hline 3 & PC & 9 & Cylinder head & 15 & Exhaust gas probe \\
\hline 4 & Water manometer & 10 & Gas analyzer & 16 & Fuel tank \\
\hline 5 & Eddy current & 11 & Smoke meter & & \\
\hline 6 & Intake air & 12 & PT-100 sensor & & \\
\hline
\end{tabular}

Fig (1) Schematic Diagram of Experimental Set Up 
Journal of University of Babylon for Engineering Sciences, Vol. (26), No. (7): 2018.
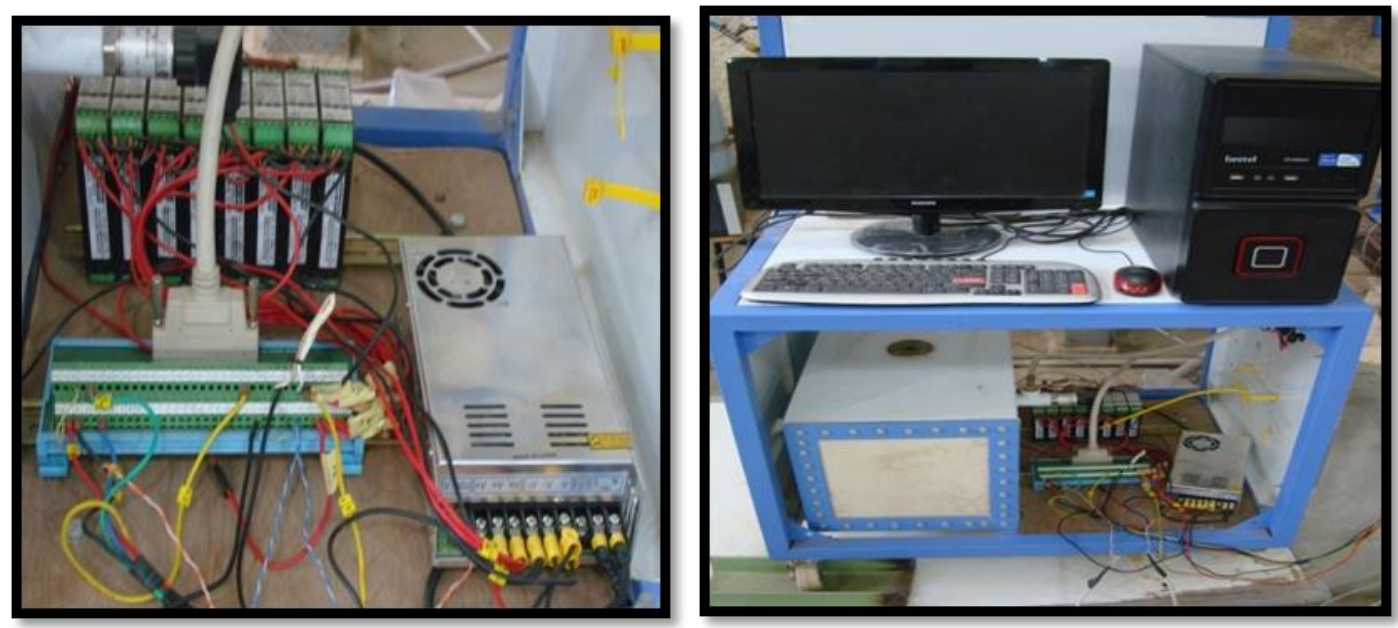

Plate (2) Data Acquisition System

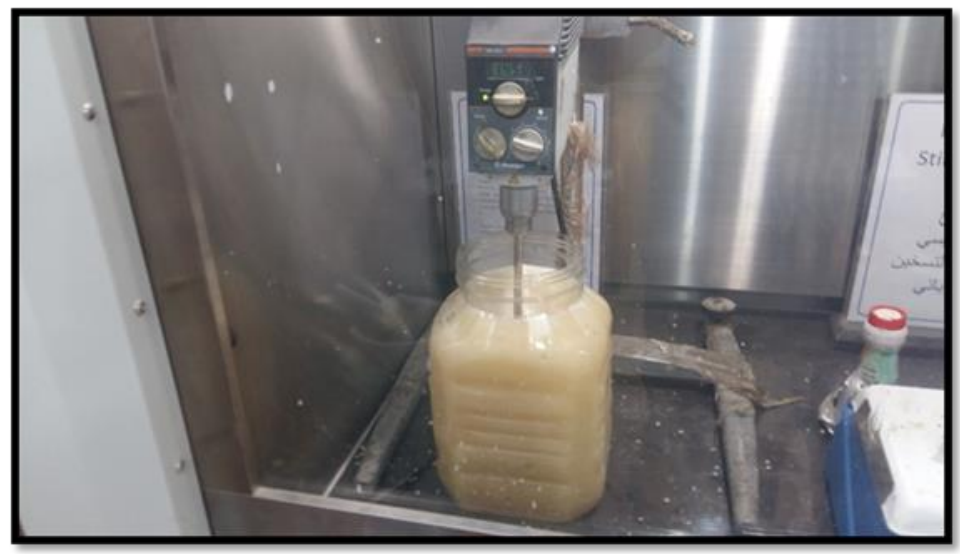

Plate (3) Photograph of a Mixer
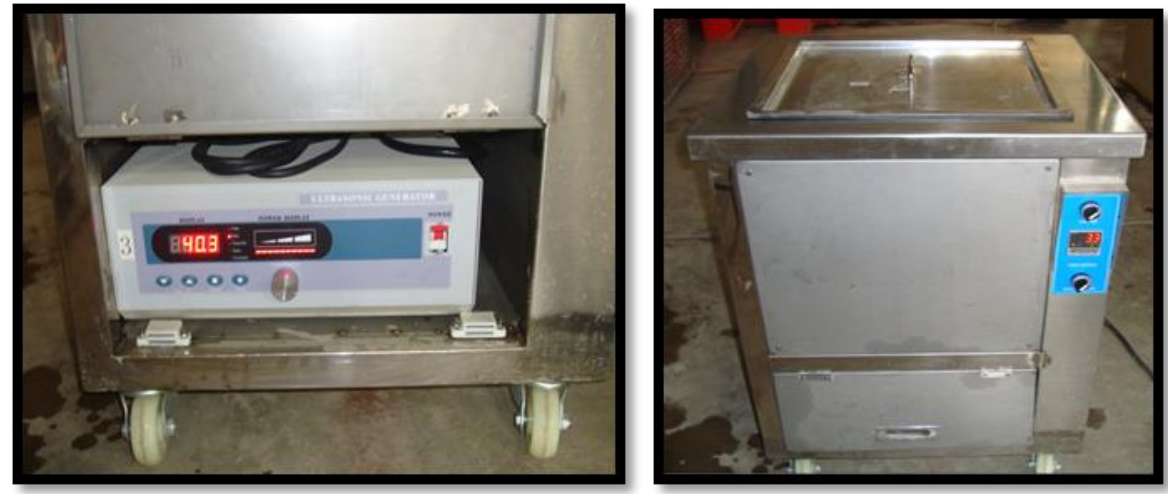

Plate (4): A Photograph of an Ultrasonic Cleaner 
Journal of University of Babylon for Engineering Sciences, Vol. (26), No. (7): 2018.

Table (3) Specifications of Ultrasonic Cleaner Bath

\begin{tabular}{|l|l|}
\hline \multicolumn{1}{|c|}{ Model } & \multicolumn{1}{c|}{ JTS-1018 } \\
\hline |Tanks working dimension $(\mathrm{mm})$ & $\mathrm{L}_{1}=406, \mathrm{~W}_{1}=305, \mathrm{H}_{1}=460$ \\
\hline Overall dimension $(\mathrm{mm})$ & $\mathrm{L}_{1}=586, \mathrm{~W}_{1}=485, \mathrm{H}_{1}=680$ \\
\hline Ultrasonic frequency & $40 \mathrm{kHz}$ \\
\hline Ultrasonic power & $720 \mathrm{Watt}$ (variable) \\
\hline Digital timer control & $1-30 \mathrm{~min}$ \\
\hline Capacity & 54 liter \\
\hline Temperature control range $\left({ }^{\circ} \mathrm{C}\right)$ & $<90^{\circ} \mathrm{C}$ \\
\hline Ultrasonic power output & $800 \mathrm{~W}$ \\
\hline
\end{tabular}

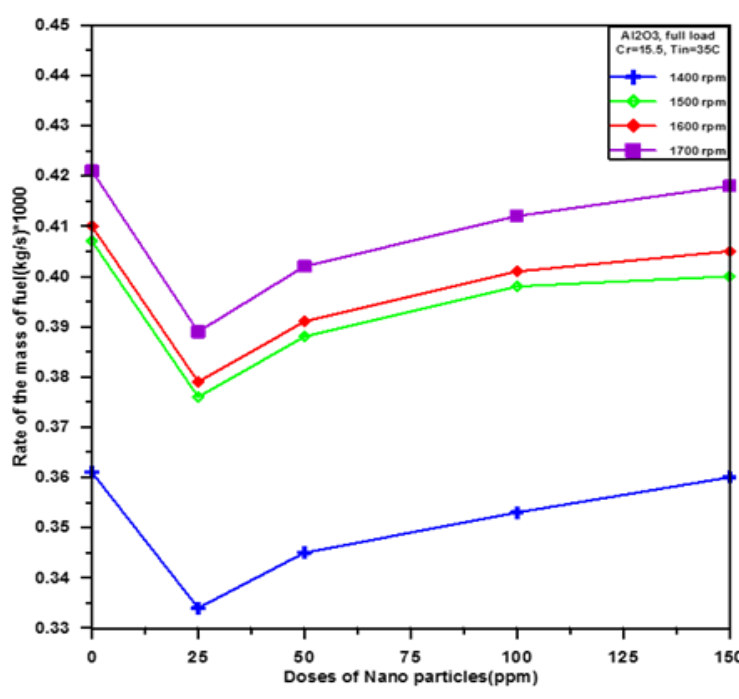

Fig 1: Variation of rate of fuel consumption with nanoparticles dose.

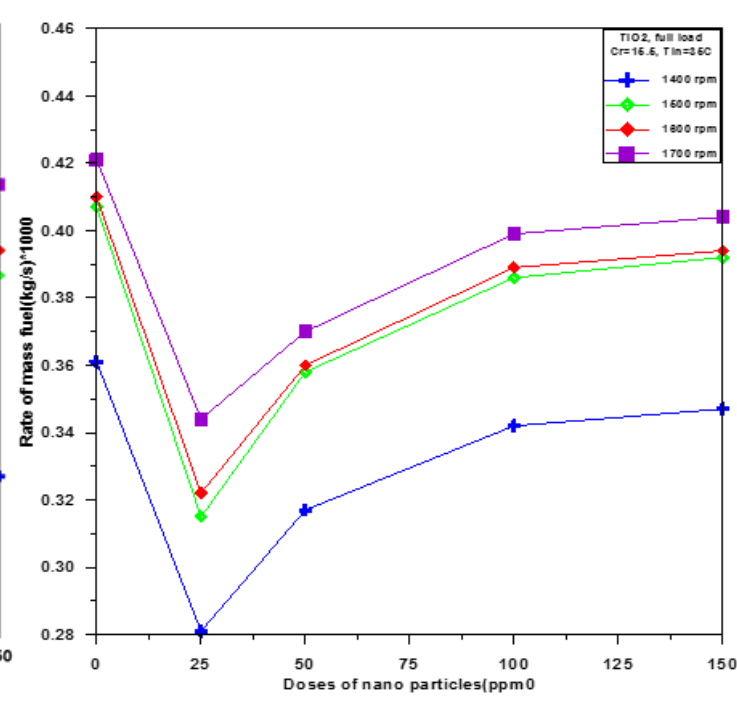

Fig 2: Variation of rate of fuel consumption with nanoparticles dose. 
Journal of University of Babylon for Engineering Sciences, Vol. (26), No. (7): 2018.

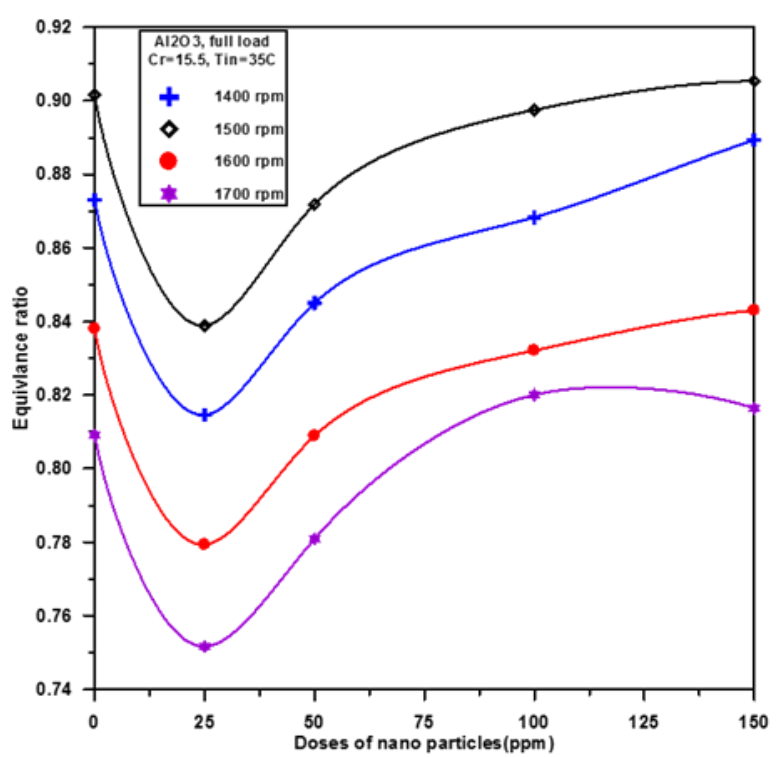

Fig 3: Variation of equivalence ratio with nanoparticles dose.

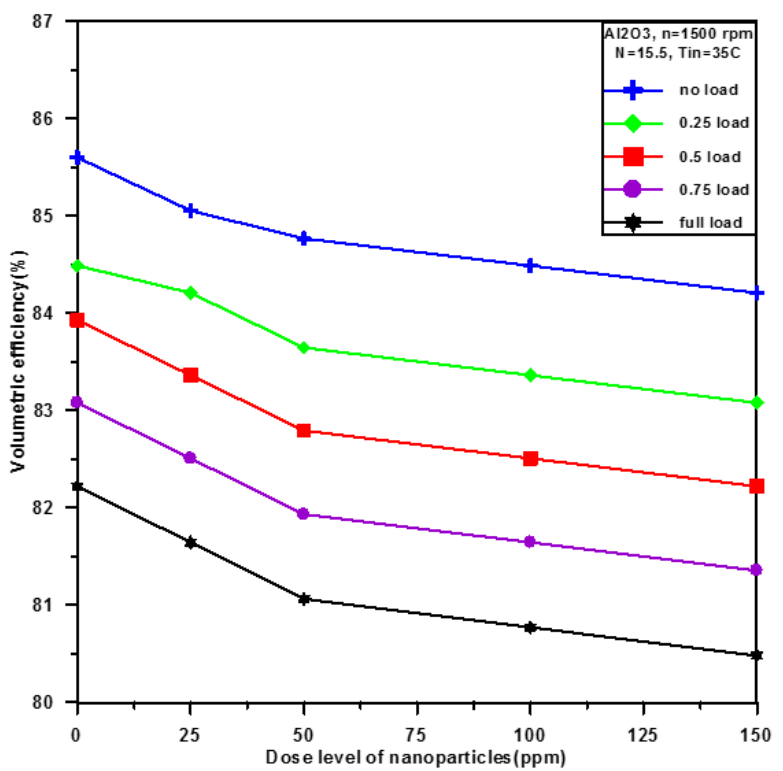

Fig 5: Variation of volum etric efficiency with nanoparticles dose.

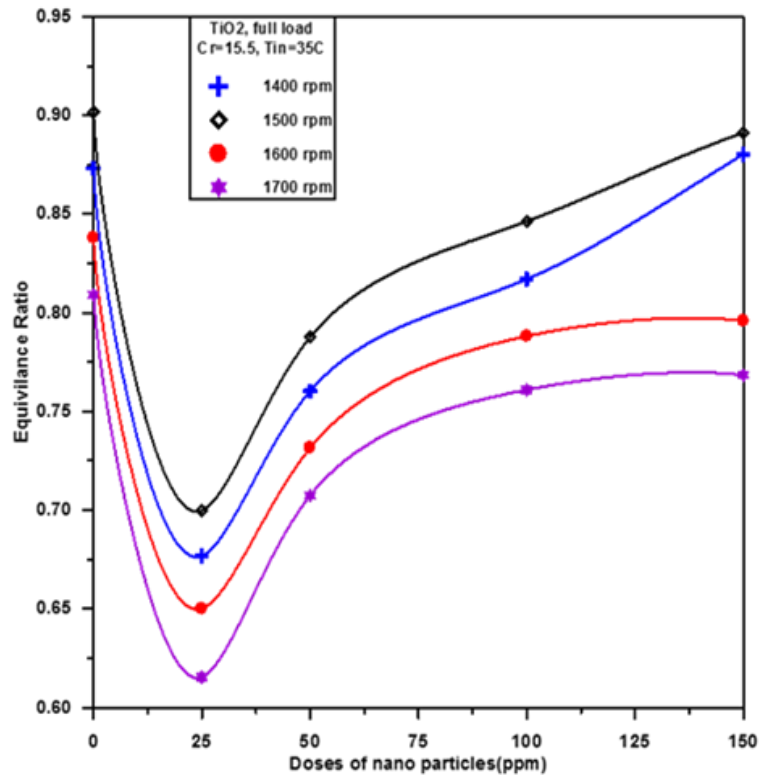

Fig 4: Variation of equivalence ratio with nanoparticles dose.

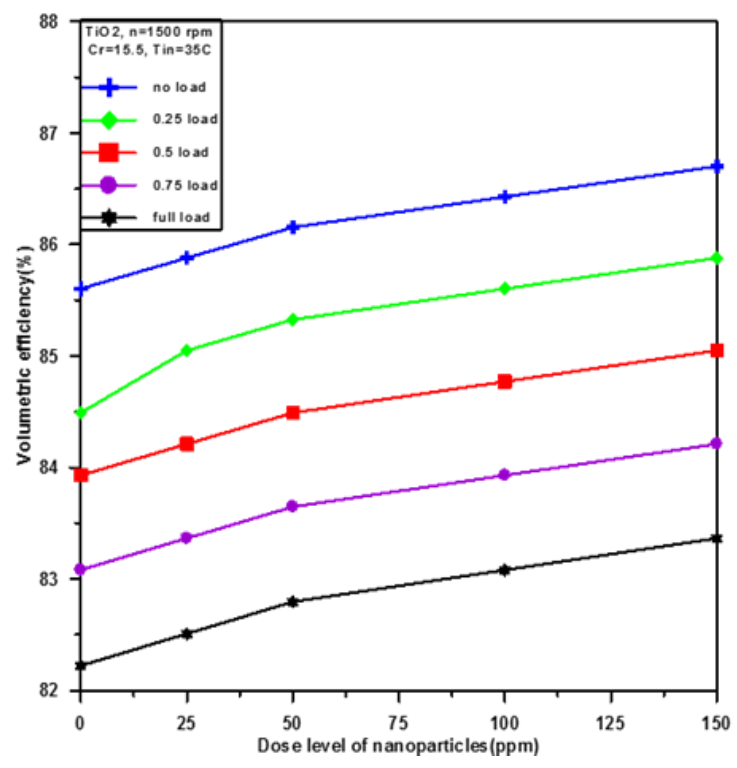

Fig 6: Variation of volumetric efficiency with nanoparticles dose. 
Journal of University of Babylon for Engineering Sciences, Vol. (26), No. (7): 2018.

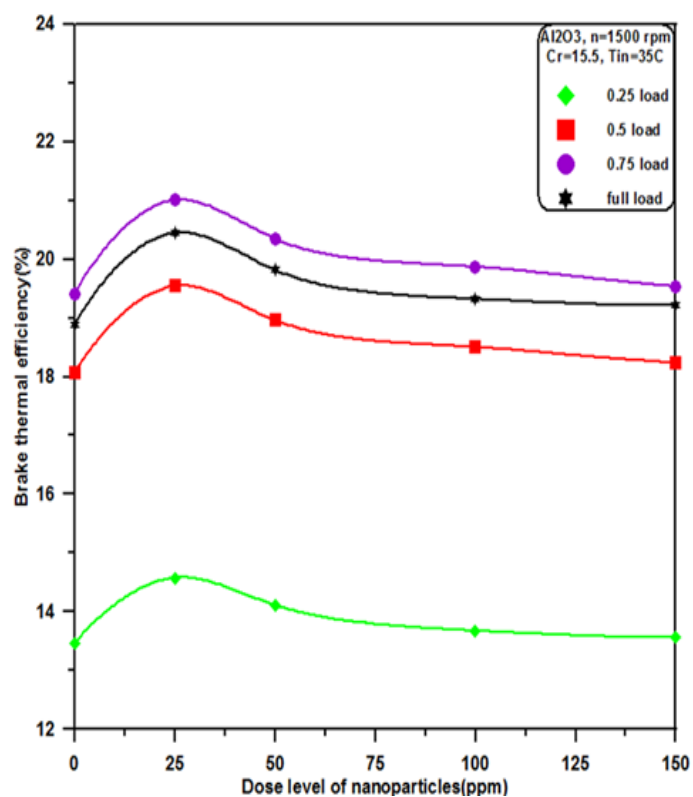

Fig 7: Variation of brake thermal efficiency with nanoparticles dose.

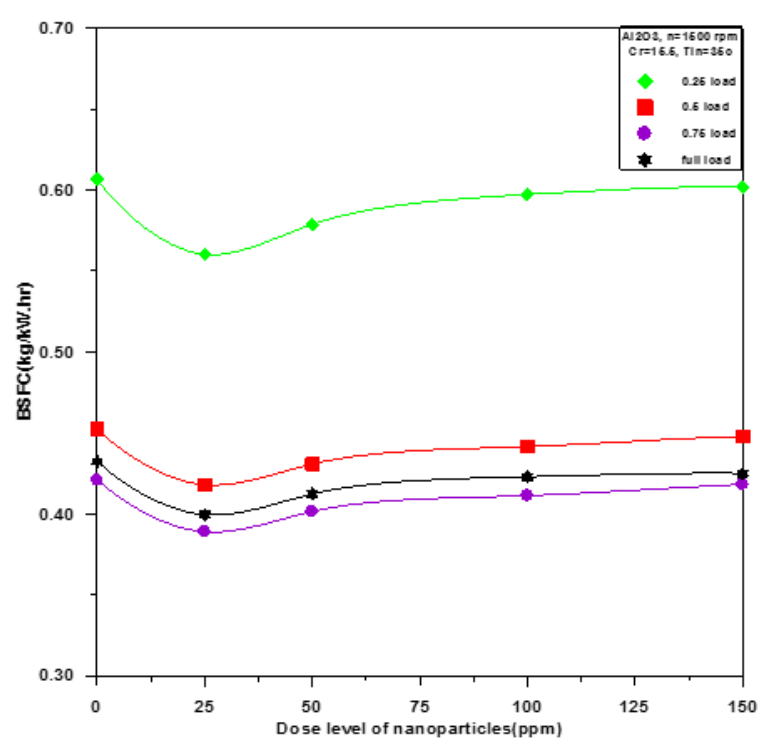

Fig 9: Variation of brake specific fuel consumption with nanoparticles dose.

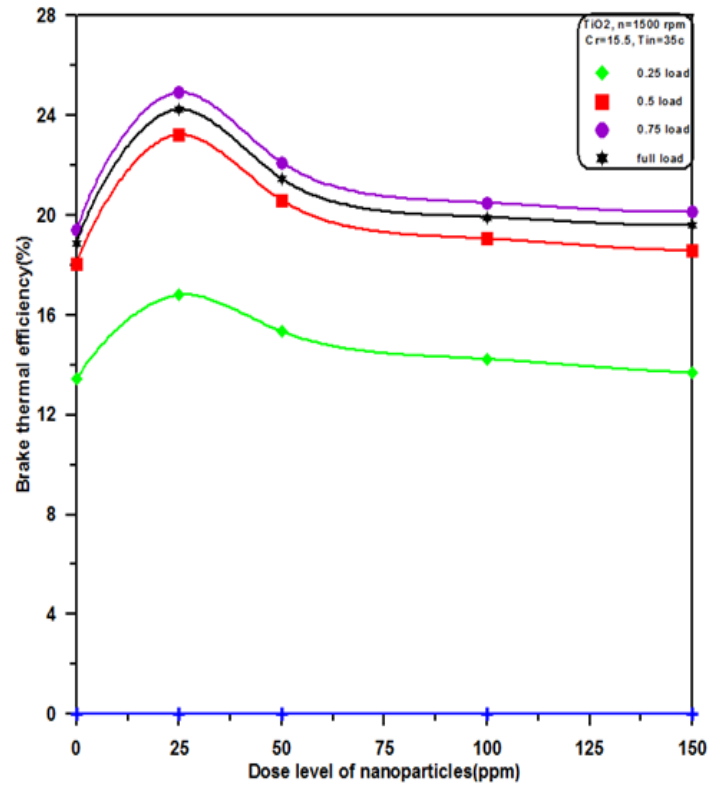

Fig 8: Variation of brake thermal efficiency with nanoparticles dose.

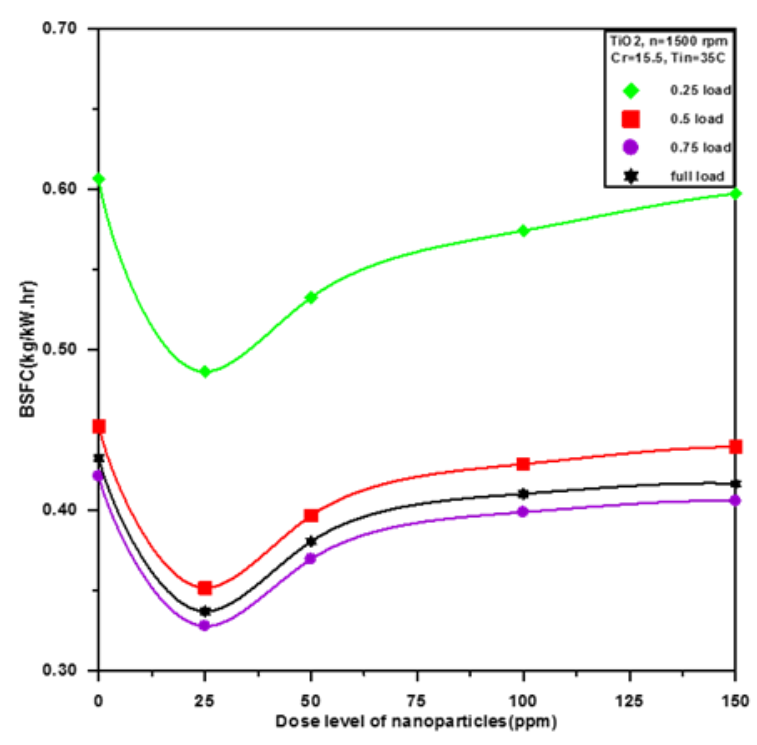

Fig 10: Variation of brake specific fuel consumption with nanoparticles dose. 
Journal of University of Babylon for Engineering Sciences, Vol. (26), No. (7): 2018.
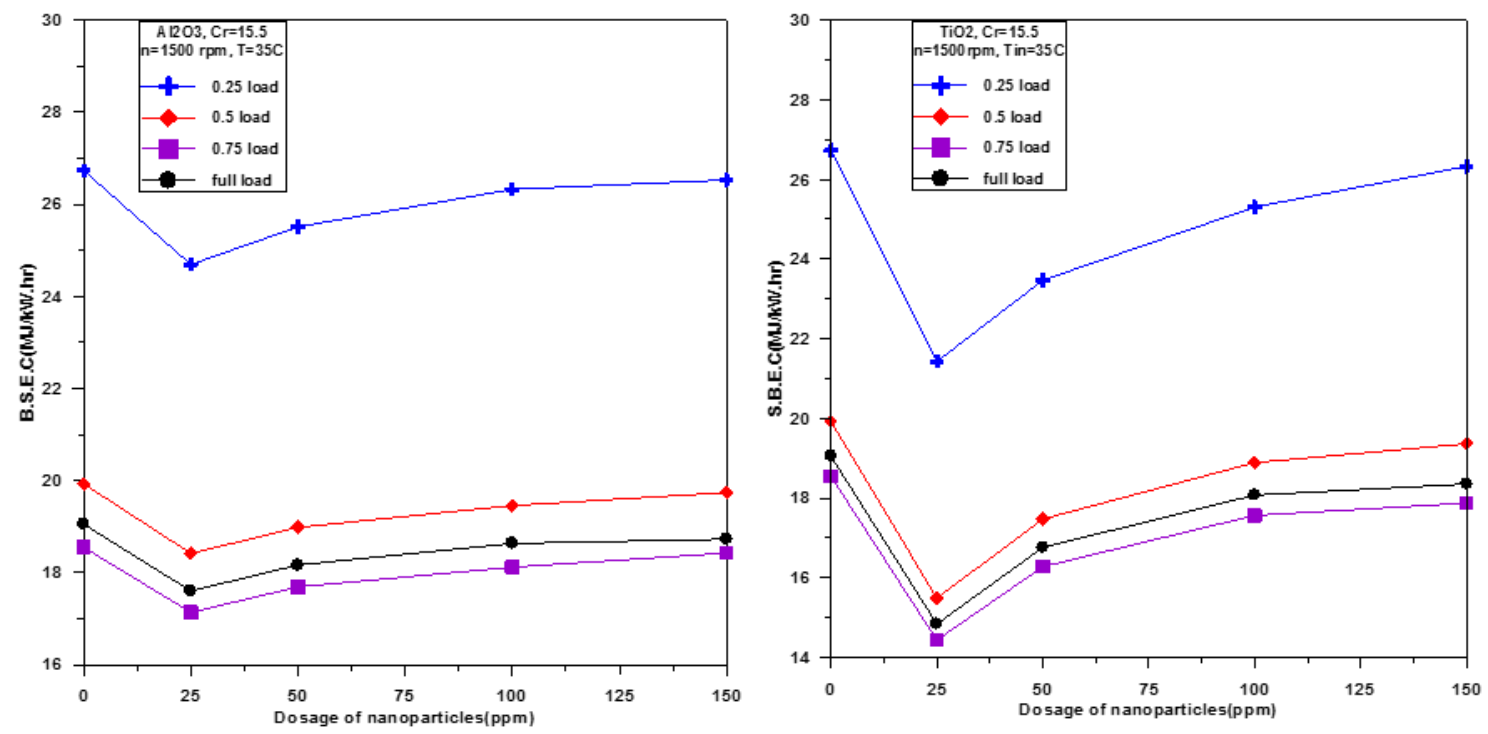

Fig 11: Variation of brake specific energy consumption with nanoparticles
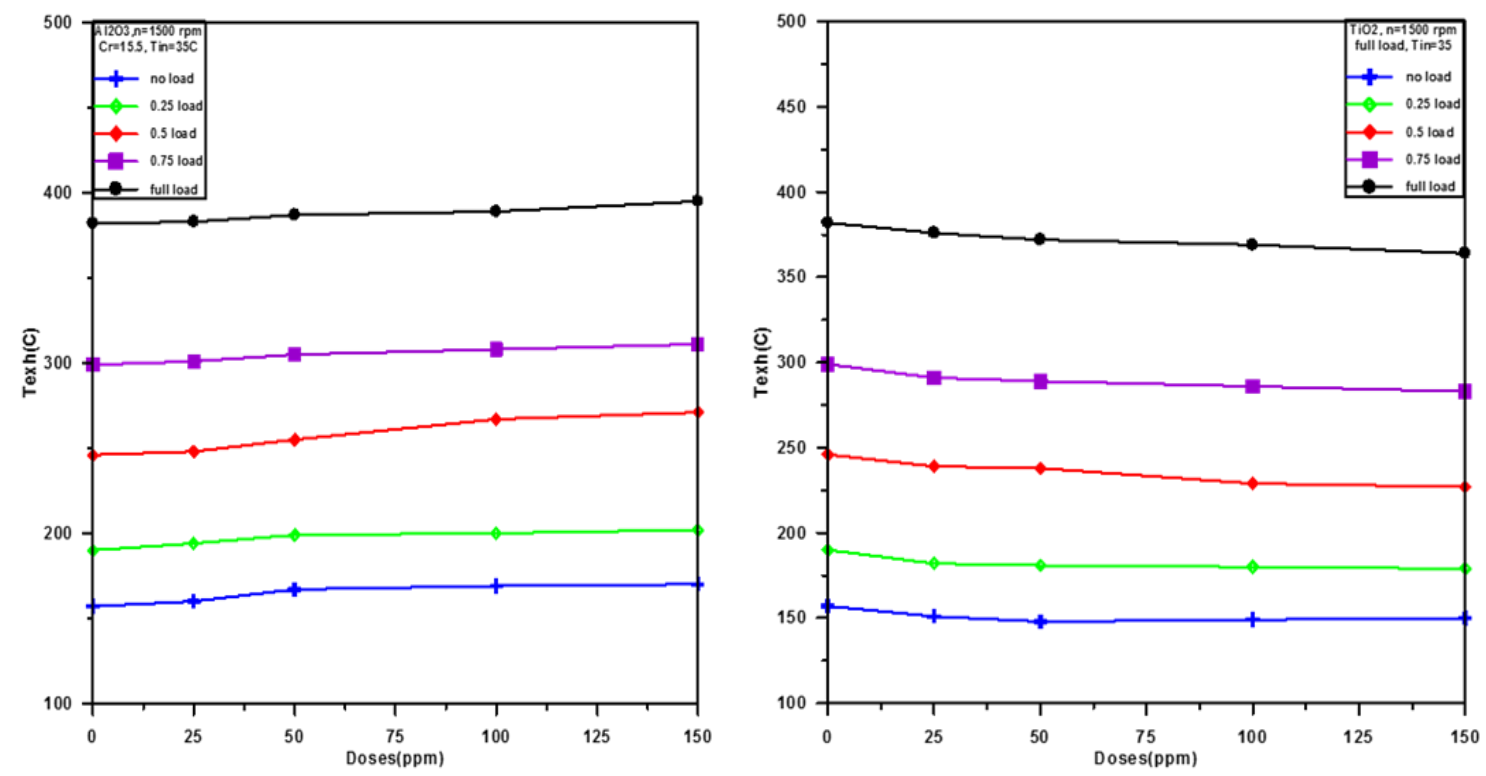

Fig 13: Variation of the ex haust temperature with nanoparticles dose.

Fig 14: Variation of the ex haust temperature with nanoparticles dose. 
Journal of University of Babylon for Engineering Sciences, Vol. (26), No. (7): 2018.

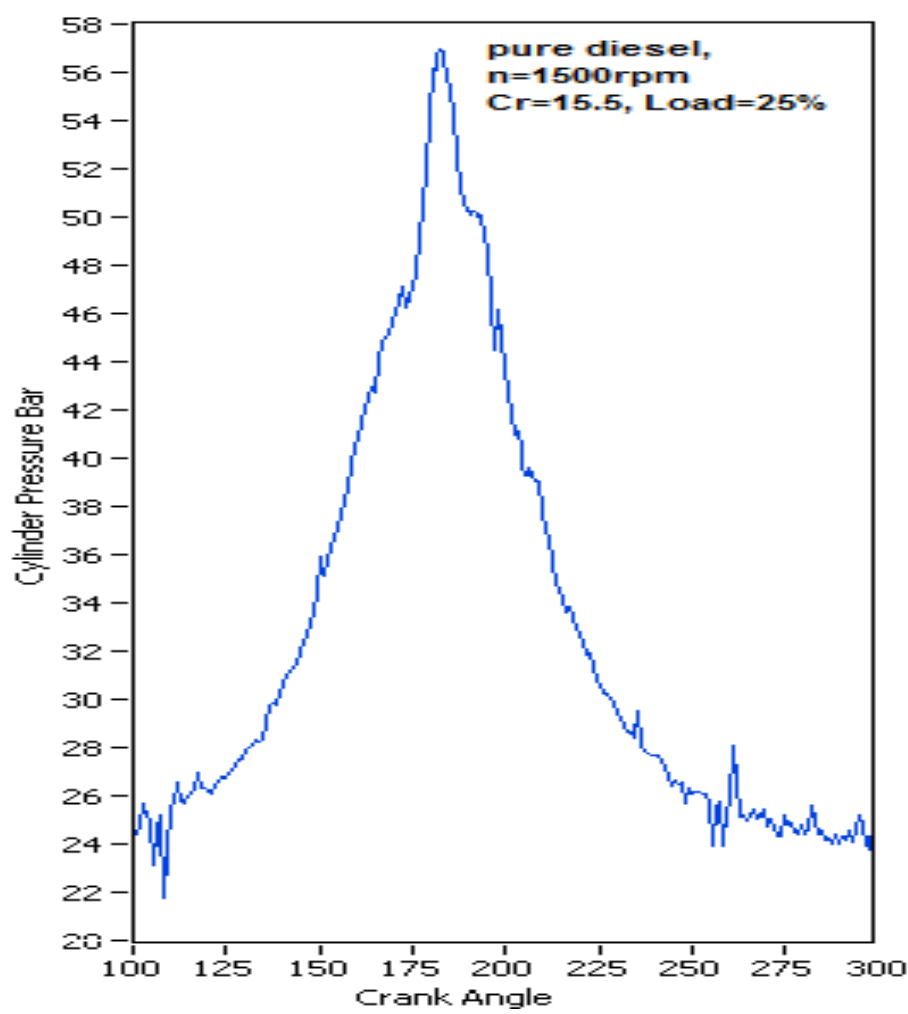

Figure (15) Cylinder Pressure History for Pure Diesel

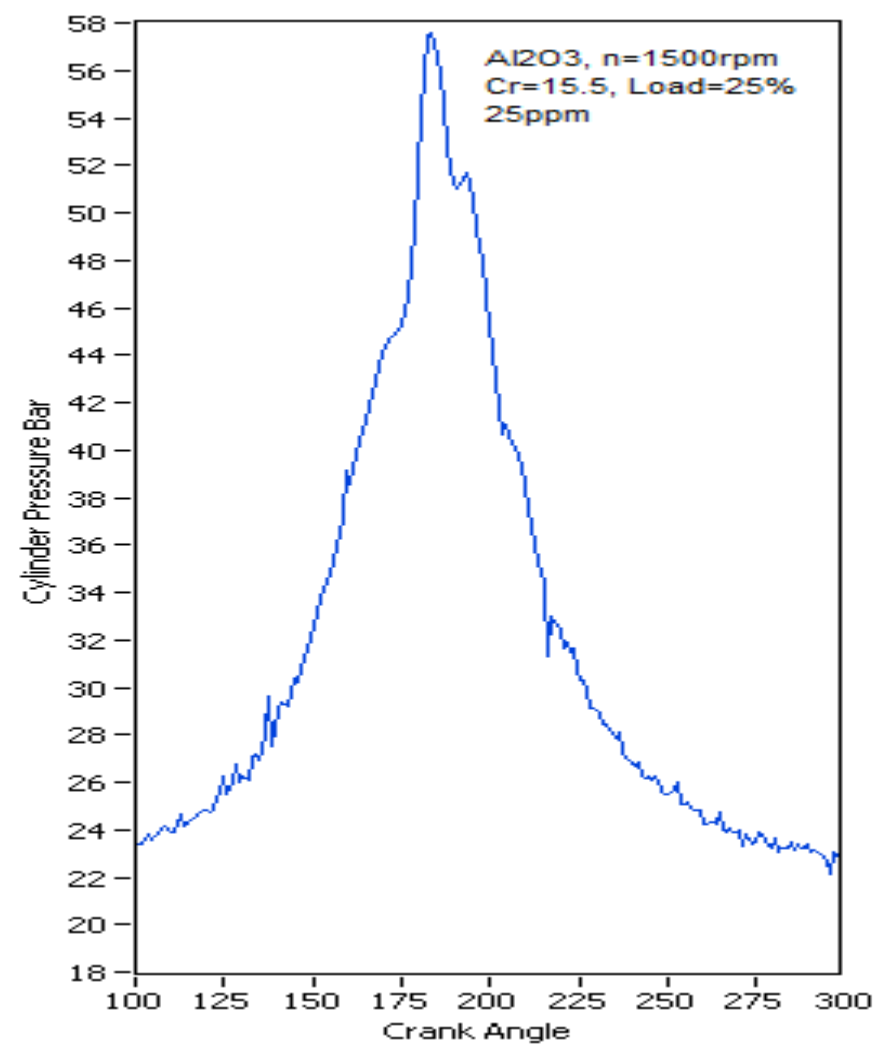

Figure (16) Cylinder Pressure History for DF+ 25ppm $\mathrm{Al}_{2} \mathrm{O}_{3}$ 
Journal of University of Babylon for Engineering Sciences, Vol. (26), No. (7): 2018.

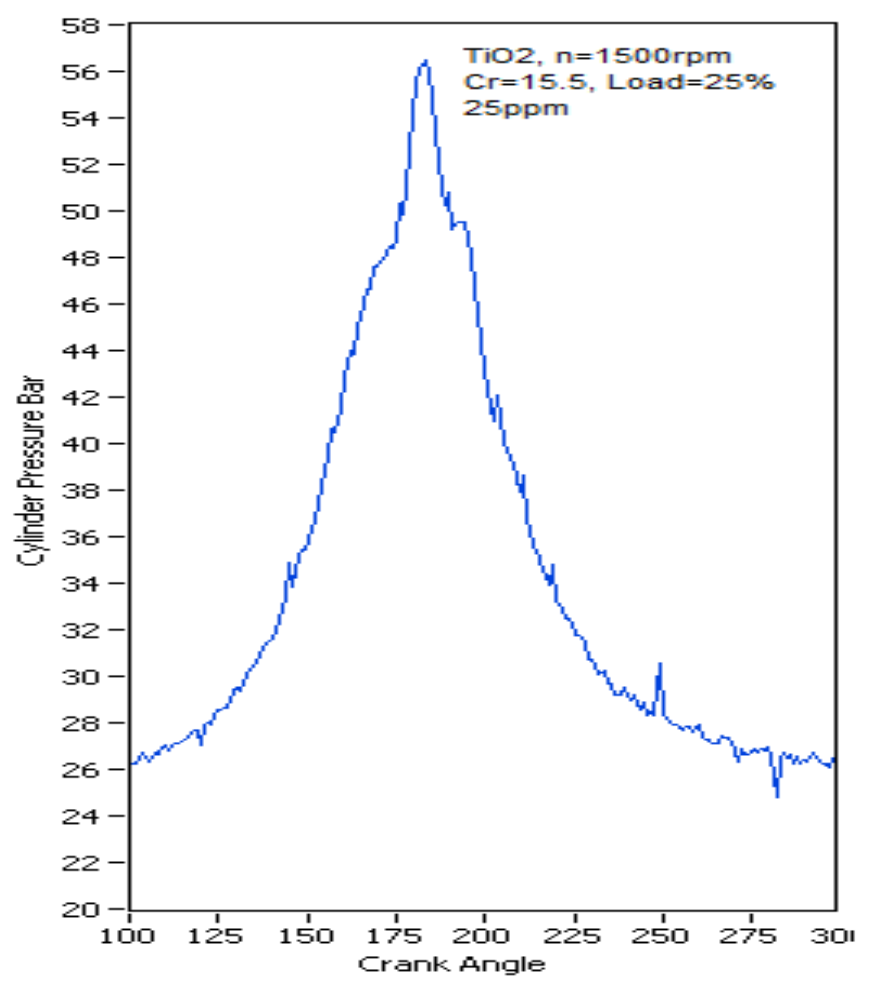

Figure (17) Cylinder Pressure History for DF+ 25ppm Tio 2

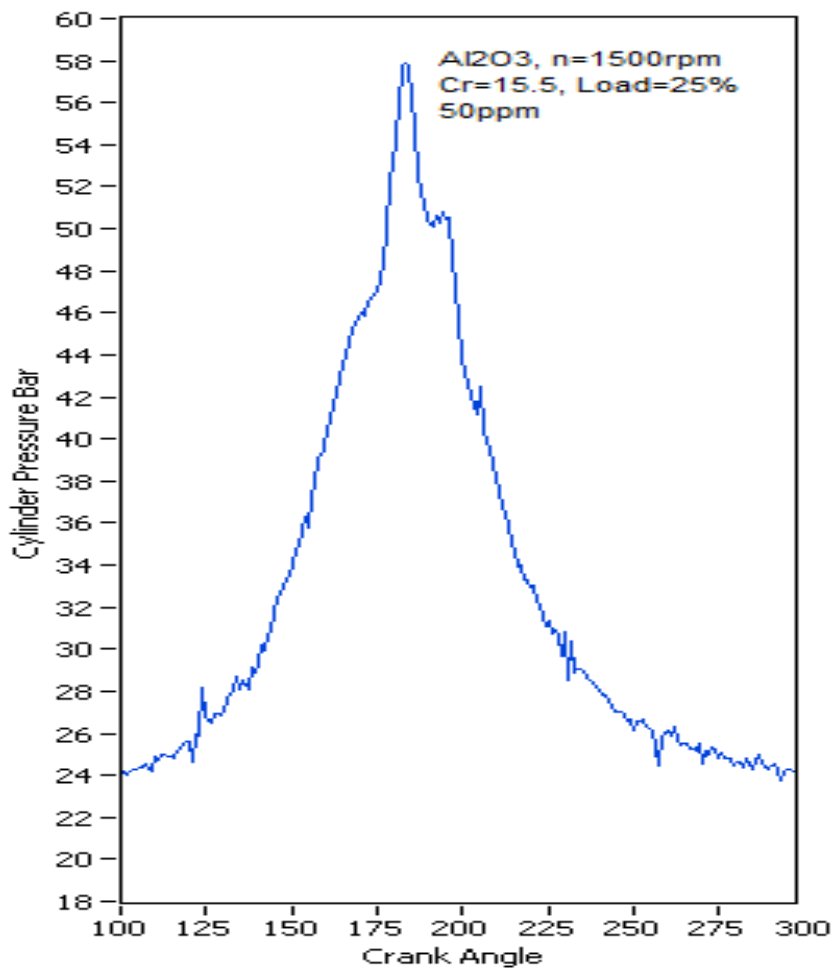

Figure (18) Cylinder Pressure History for $\mathrm{DF}+50 \mathrm{ppm} \mathrm{Al}_{2} \mathrm{O}_{3}$ 
Journal of University of Babylon for Engineering Sciences, Vol. (26), No. (7): 2018.

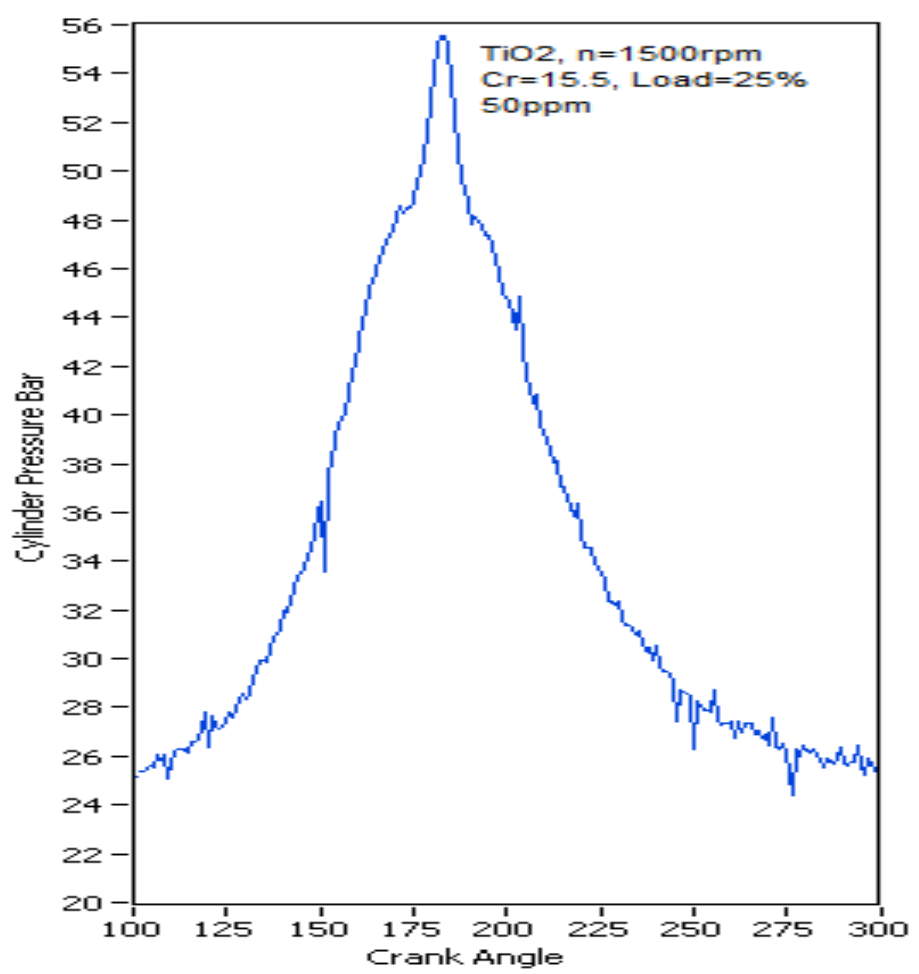

Figure (19) Cylinder Pressure History for DF+ 50ppm Tion

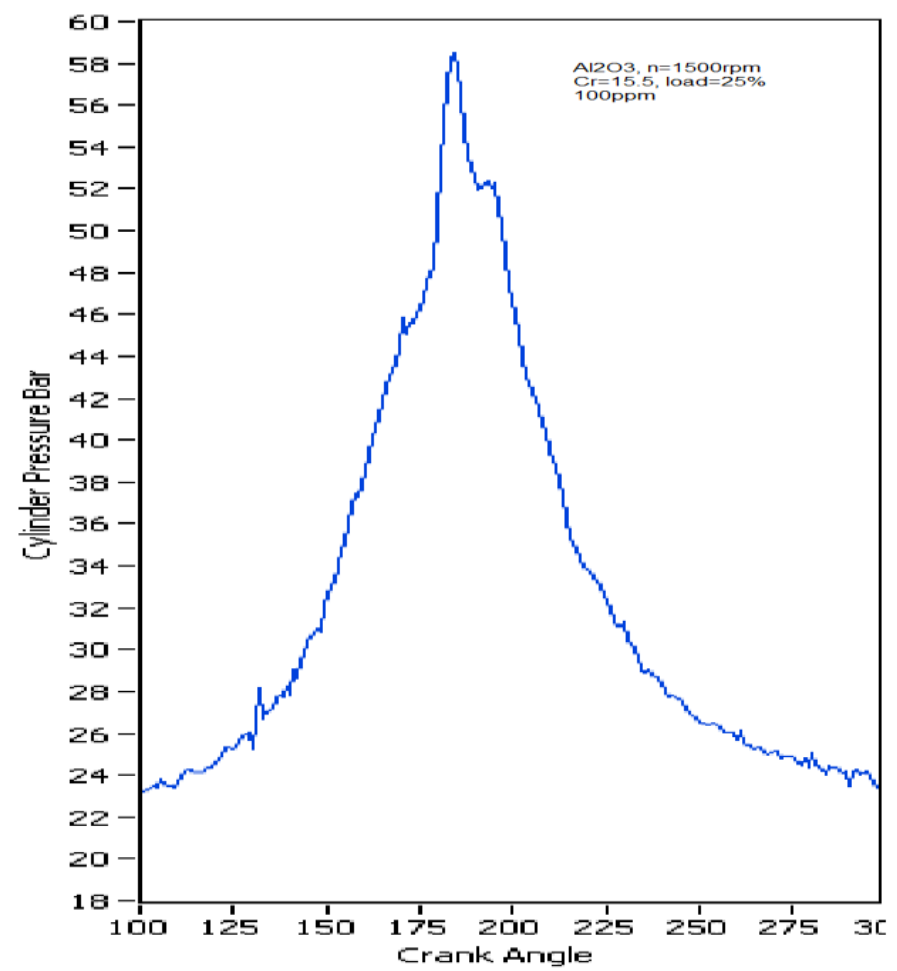

Figure (20) Cylinder Pressure History for $\mathrm{DF}+100 \mathrm{ppm} \mathrm{Al}_{2} \mathrm{O}_{3}$ 
Journal of University of Babylon for Engineering Sciences, Vol. (26), No. (7): 2018.

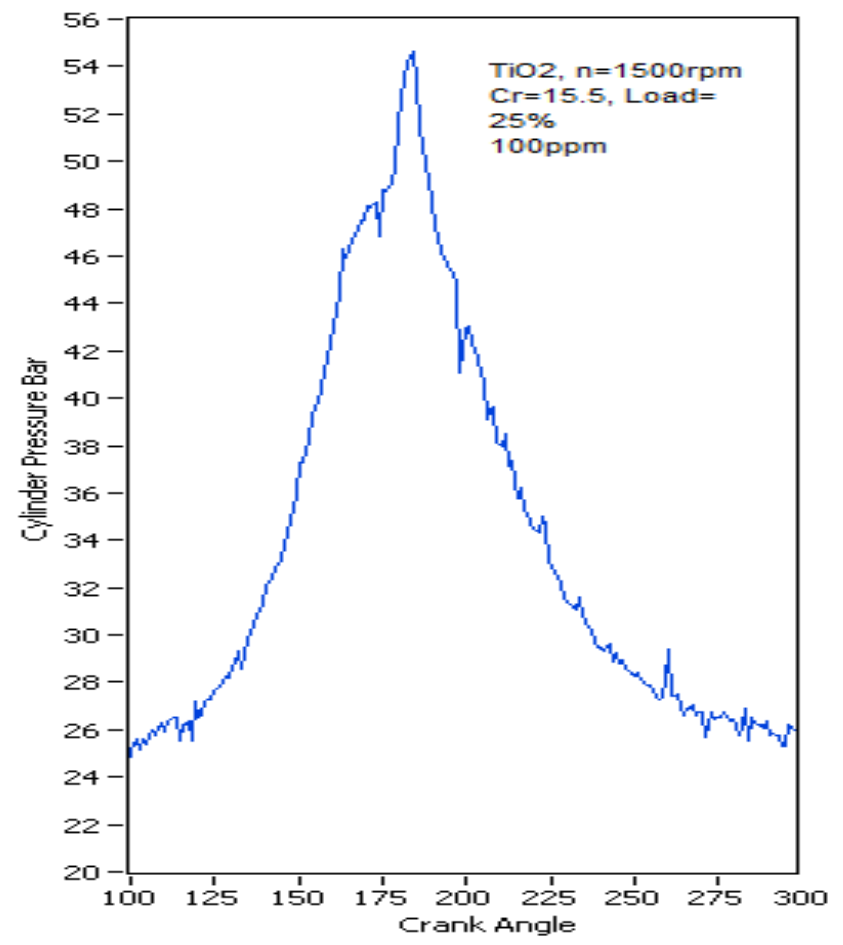

Figure (21) Cylinder Pressure History for DF+ 100ppm Tion

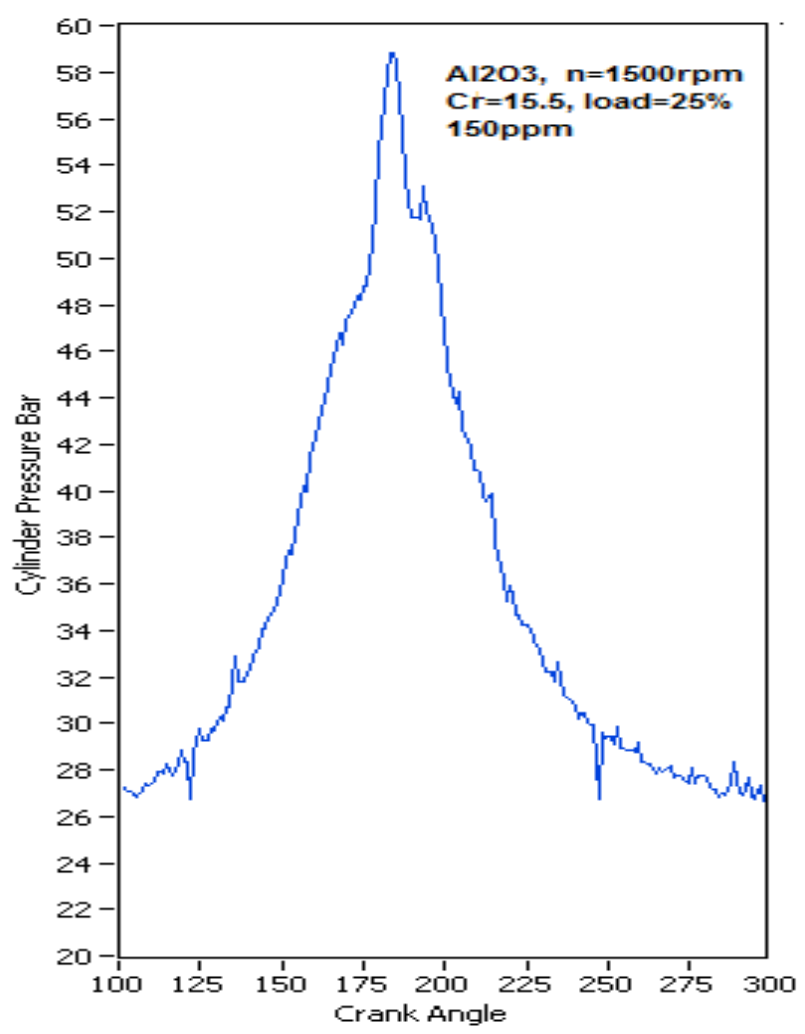

Figure (22) Cylinder Pressure History for DF+ 150ppm $\mathrm{Al}_{2} \mathrm{O}_{3}$ 
Journal of University of Babylon for Engineering Sciences, Vol. (26), No. (7): 2018.

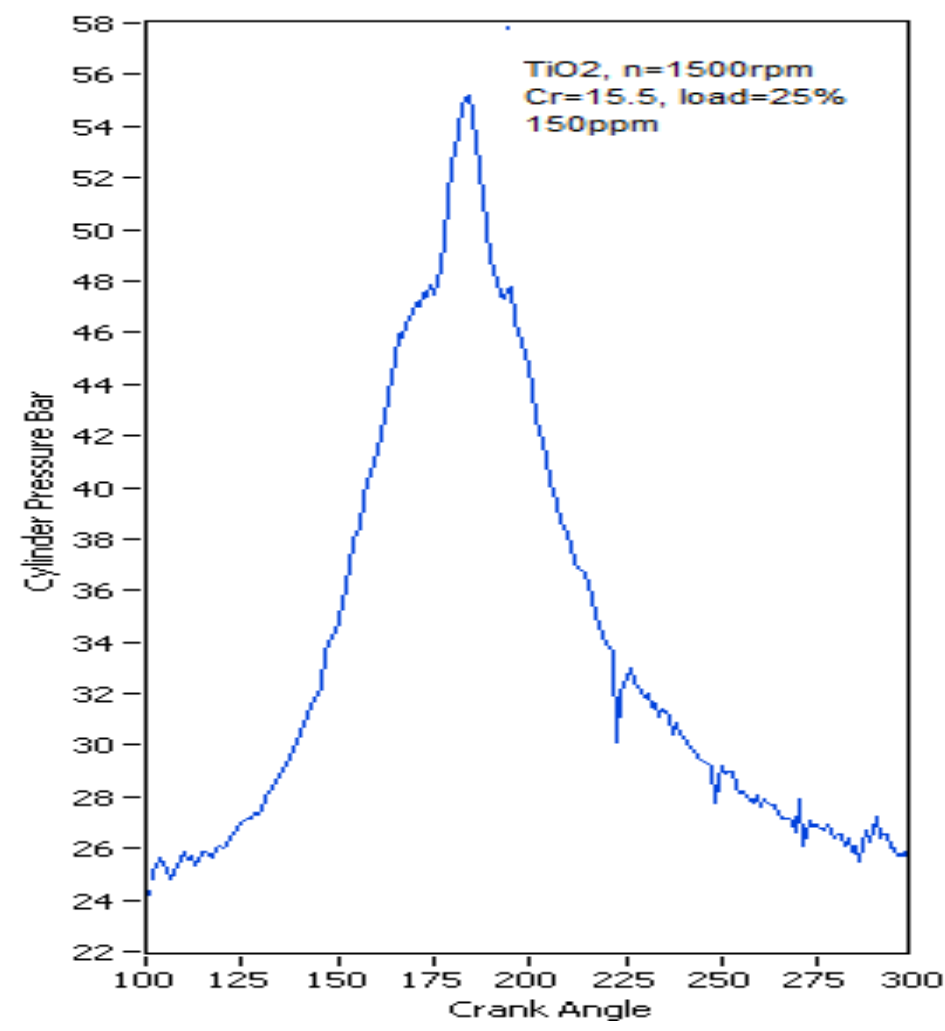

Figure (23) Cylinder Pressure History for DF+150ppm Tioz 
Journal of University of Babylon for Engineering Sciences, Vol. (26), No. (7): 2018.
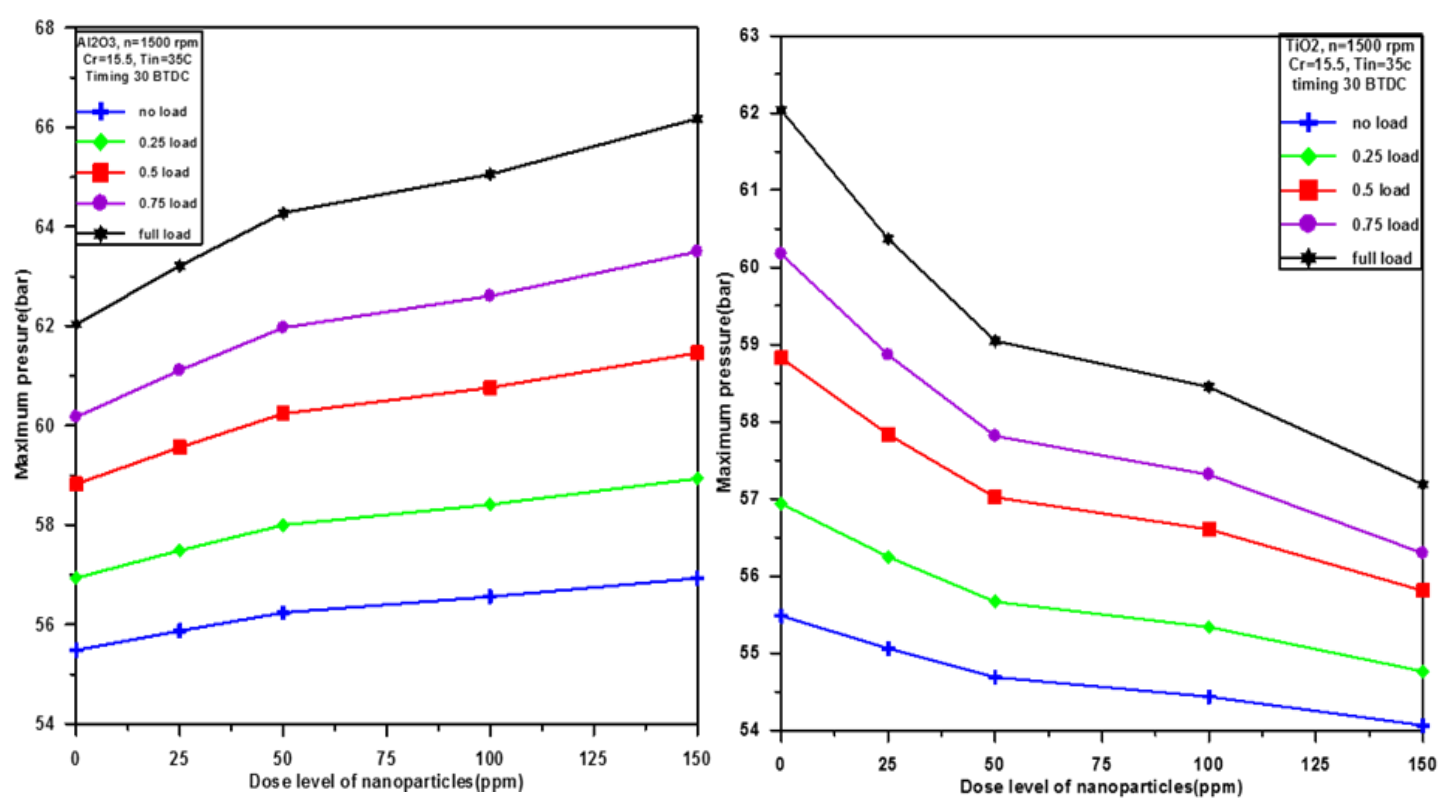

Figs $24 \& 25:$ Variation of the maximum pressure with nanoparticles dose

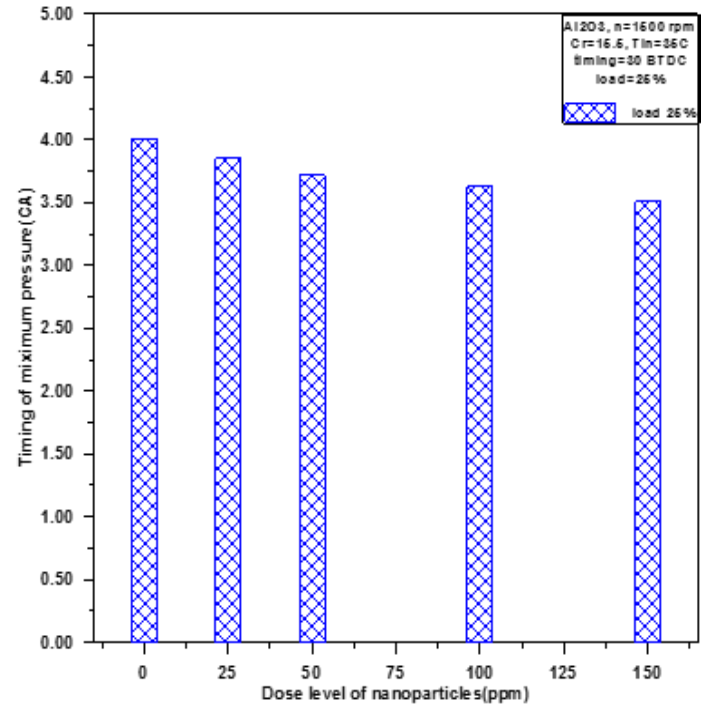

Fig 26: Variation of the timing of max im um pressure with dose of nanoparticles.

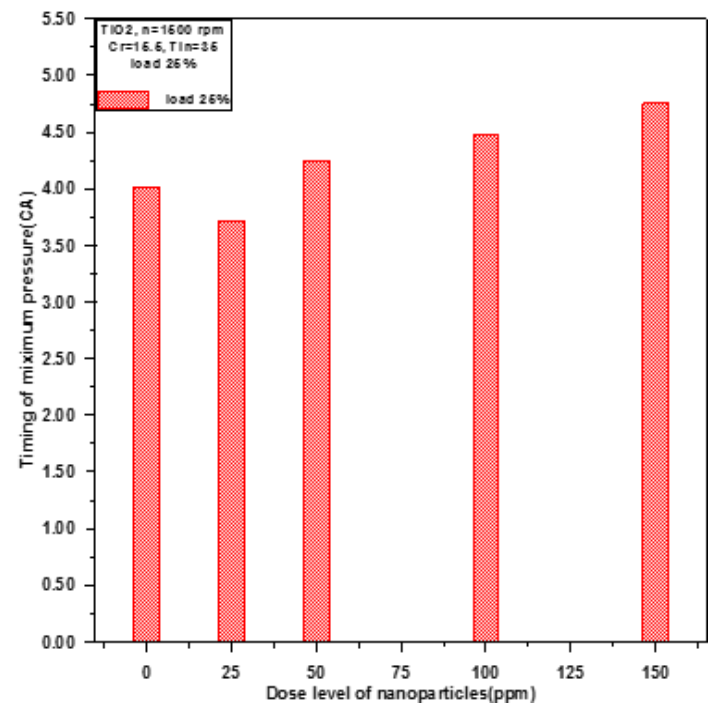

Fig 27: V ariation of the timing of the maximum pressure with dose of nanoparticles. 
Journal of University of Babylon for Engineering Sciences, Vol. (26), No. (7): 2018.

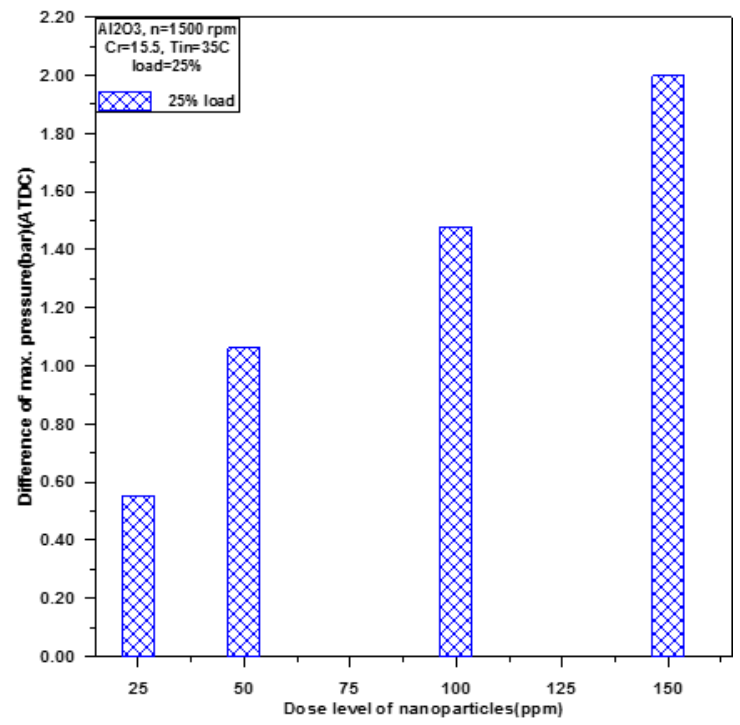

Fig 28 Variation of $\Delta p_{\max }$ with Nanoparticles Dose

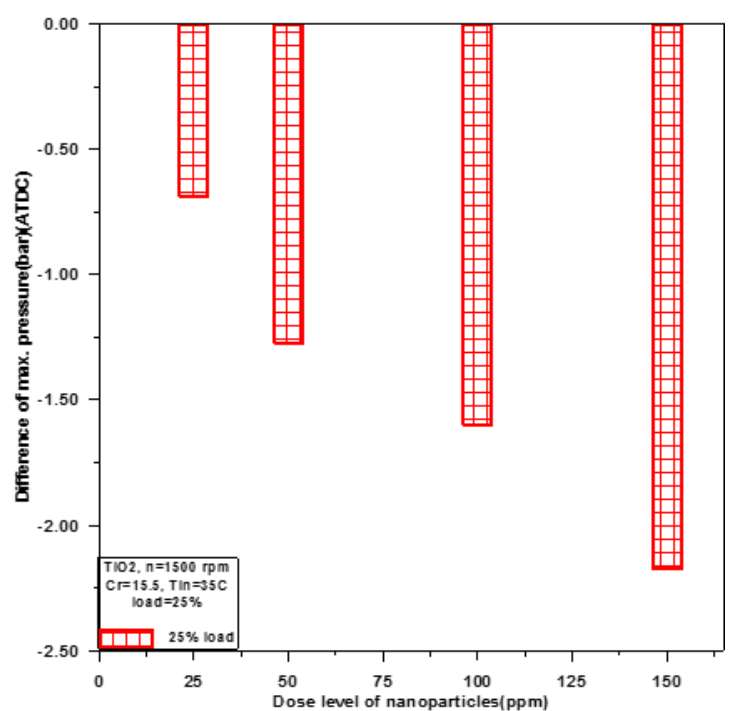

Fig 29 Variation of $\Delta p_{\max }$ with Nanoparticles Dose 


\title{
در اسه عملية لاداء محرك ديزل يعمل بانواع مختلفه من وقود الديزل النانوي
}

\author{
هارون عبد الكاظم شهد \\ عبد الخضر كاظم ناصر \\ قسم الهندسه المبكانيكبه، كلية المندسه، جامعة بابل \\ hakshahad@yahoo.com \\ alhaji84@yahoo.com
}

الخلاصة

تم في هذا البحث در اسه عمليه حول ناثير اضافة حبيبات متتاهيه في الصغر (حبيبات النانو) الى وقود

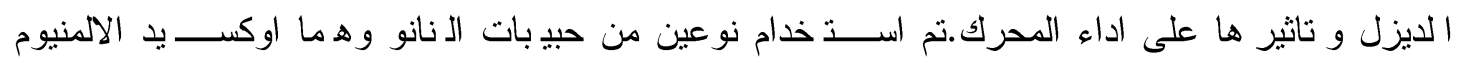

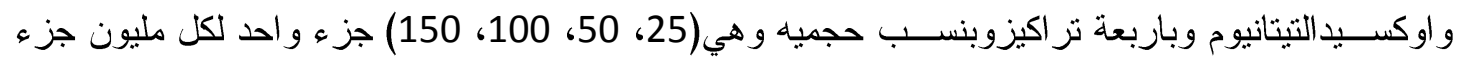

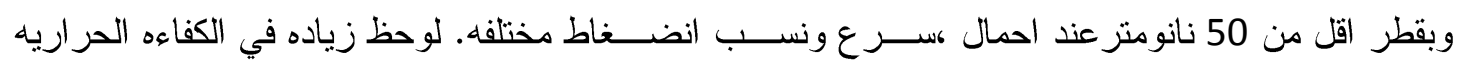
المكبحيه مع (ديزل+اوك سيد الالمنيوم) 21\% ومع (ديزل+اوك سيد التيتانيوم) 25\% مقارنة مع وقود الديزل النقي .اما اسـتههلاك الوقود النوعي المكبحي قل20\% و 8\% (ديزل + اوكسـيد التيتانيوم) و (ديزل+اوكسـيد

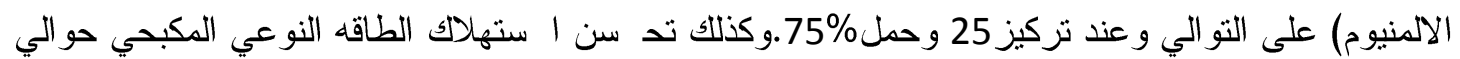

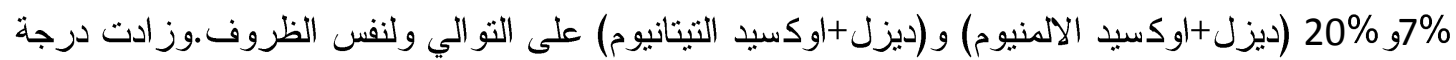

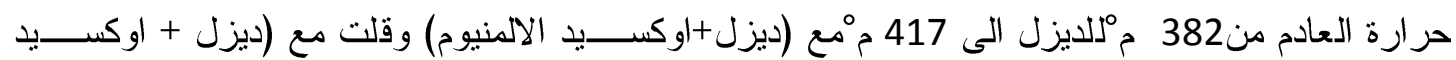

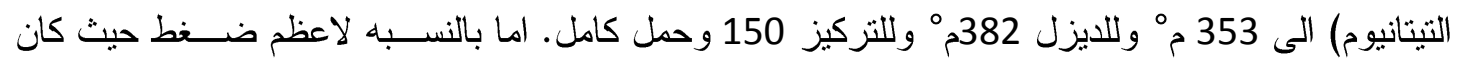

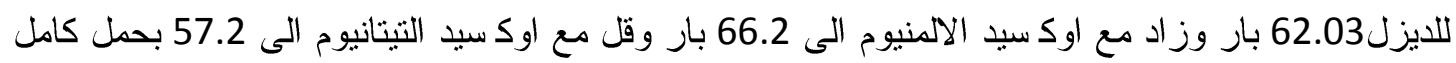

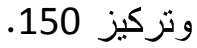
الكلمات المفتاحيه: - الوقود النانوي، حبيبات النانو، أداء المجرك، محرك الديزل. 